\title{
Örgütsel adaletin örgütsel sessizliğe etkisinde yöneticiye duyulan güvenin düzenleyici rolü
}

\section{The role of trust for the manager in the effect of organizational justice on organizational silence}

${ }^{1}$ Dr. Ö $\breve{g}$. Grv. Milli Savunma Üniversitesi, Balıkesir, Türkiye, arzuugurlukara@outlook.com

ORCID: 0000-0001-9348-6107

2 Doç. Dr. Milli Savunma Üniversitesi, Ankara, Türkiye, begenirbas@kho.edu.tr ORCID: 0000-0003-0917-0973

\section{Sorumlu Yazar/Corresponding Author:}

Arzu Uğurlu Kara,

Milli Savunma Üniversitesi, Balıkesir, Türkiye, arzuugurlukara@outlook.com

Başvuru/Submitted: 26/05/2021

Revizyon/Revised: 24/06/2021

Kabul/Accepted: 3/07/2021

Yayın/Online Published: 25/09/2021

Atıf/Citation: Uğurlu Kara, A., \& Beğenirbaş, M., Örgütsel adaletin örgütsel sessizliğe etkisinde yöneticiye duyulan güvenin düzenleyici rolü, bmij (2021) 9 (3): 956-975, doi: https://doi.org/10.15295/bmij.v9i3.1850

\author{
Arzu Uğurlu Kara ${ }^{1}$ \\ Memduh Beğenirbaş²
}

Öz

Günümüzde herkes değişimin her örgüt tarafından dikkat edilmesi gereken bir unsur olduğunu bilmektedir. Üniversiteler de sektörlere insan sermayesi sağlayan örgütler olarak bu değişim karşısında kendini sürekli yenileyen bir örgüt iklimi yapısına sahip olmalıdır. Bunun için yaratıcı fikirlerin üretildiği, herkesin kararlara katıldığı, kısacası çalışanların ses çıkarıp örgütsel sessizliğe bürünmediği örgüt yapılarına ihtiyaç duyulmaktadır. Bu maksatla tüm bunlara zemin oluşturmayı kolaylaştıracak olumlu örgütsel adalet algısının olușturulması ve akademisyenlerin bu ortamı oluşturacak yöneticilerine güven duyması üniversiteler için hayati öneme sahiptir. Bu çalışmada 236 akademisyenden elde edilen veriler ıșığında; akademisyenlerin örgütsel adalet algıları ile örgütsel sessizlik davranışları arasındaki ilişkide yöneticiye duyulan güvenin düzenleyici etkisi araştırılmıştır. Çalışmada değişkenler arası ilişkiler ve etkileri korelasyon ve regresyon analizleri ile ortaya konulmuş, düzenleyici etki regresyon eğrisi ile ayrıca sınanmıştır. Elde edilen bulgulara göre, akademisyenlerin örgütsel adalet algılarındaki artış, örgütsel sessizlik davranışlarını azaltmaktadır. Bunun yanı sıra akademisyenlerin yöneticilerine duydukları güven duygusu örgütsel adalet algıları ile örgütsel sessizlik davranışları arasındaki ilişkide düzenleyici rol üstlenmektedir.

Anahtar Kelimeler: Güven, Örgütsel Adalet, Örgütsel Sessizlik

Jel Kodlari: M19

\begin{abstract}
Today, everyone knows that change is an element that every organization should consider. As organizations that provide human capital to the sectors, universities should have an organizational climate structure that constantly renews itself with this change. For this, organizational structures in which creative ideas are produced and everyone participates in the decisions, that is, the employees do not fall into an organizational silence are needed. For this purpose, universities need to create a positive perception of organizational justice that will facilitate the foundation for all these and that academics trust their managers who will create this environment. In this study, in the light of the data obtained from 236 academicians, the moderating effect of trust to the manager in the relationship between the perceptions of academicians of organizational justice and organizational silence behaviours was investigated. In the study, correlation and regression analyses revealed the relations between the variables and their effects, and the regulatory effect was also tested with a regression curve. According to the findings obtained, the increase in the perceptions of academicians of organizational justice reduces their organizational silence behaviours. In addition, the sense of trust that academicians have to their
\end{abstract}

Keywords: Trust, Organizational Justice, Organizational Silence

Jel Codes: M19 


\section{Extended Abstract}

\section{The role of trust for the manager in the effect of organizational justice on organizational silence}

Literature

\section{Research subject}

In the light of the data obtained from 236 academicians, it was investigated that the relationship between academicians' perceptions of organizational justice and their behaviours of organizational silence regulates trust in the administrator.

\section{Research purpose and importance}

According to the findings of this study, it is essential to make suggestions to those who will conduct studies on the subject, with advice to academicians (employees), university administrators (administrators), universities (organizations).

\section{Contribution of the article to the literature}

When the literature is examined, there is no study on the regulator of the trust in the manager in the relationship between organizational justice and employee silence. Therefore, this study undertakes to fill this research blank.

\section{Design and method}

The study aims to examine the regulatory role of trust in managers in the effect of silence behaviour of organizational justice perception with a quantitative technique.

\section{Research type}

The type of research is applied and descriptive study.

\section{Research problems}

To investigate the relationship between organizational justice perception and organizational silence behaviour and the regulatory role of trust in the manager in this relationship.

\section{Data collection method}

In the research scope, a survey was conducted with 261 individuals working in public or private universities in Ankara by email technique. Therefore, the quantity of valid questionnaires included in the analysis is 236 . Therefore, the quantitative research method is adopted.

\section{Quantitative/qualitative analysis}

In the research, a correlational research model was used. This model deals with the causal relationship between the variables used in this model, and accessible method information was collected from the participants in which this relationship can be tested (Büyüköztürk et al., 2008) on the scales of the variables. In the analysis phase, its confirmatory factor analysis (CFA) of a variable was conducted as an equality model (AMOS). Correlation analysis revealed the relationships between variables and hierarchical regression analysis to test the hypotheses. Regression analysis based on the Bootstrap method was performed with SPSS Process v3.5 Macro software to test the regulatory role of trust in managers under the influence of organizational silence of organizational justice perceptions of academicians.

\section{Research model}

The quantitative research method is adopted.

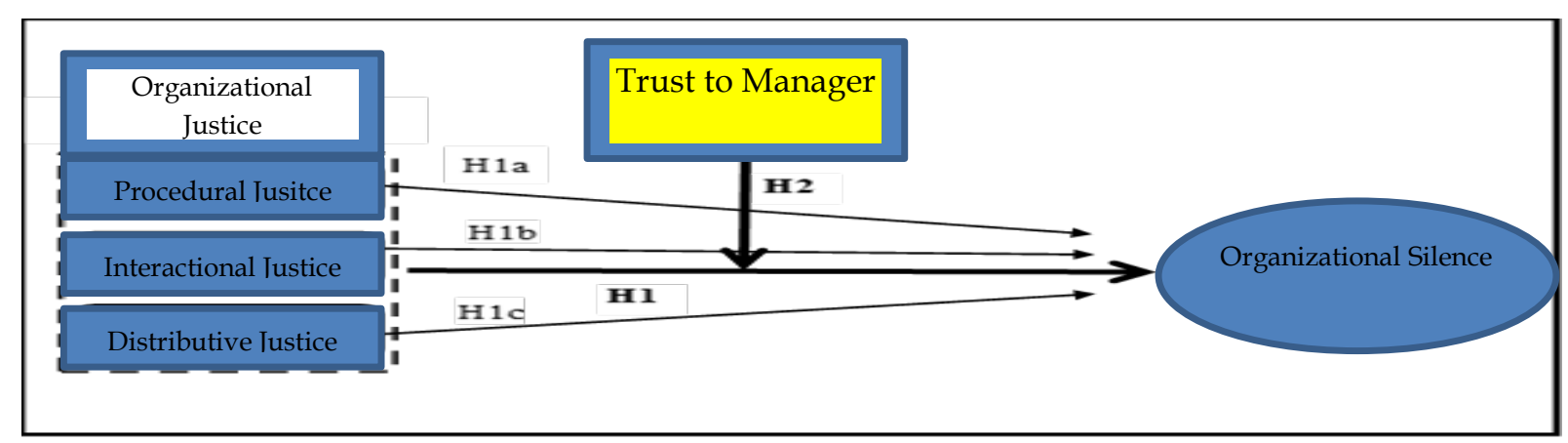

\section{Research hypotheses}

The hypotheses of the study are determined as follows;

Hypothesis 1: The perception of organizational justice affects the organizational silence of academicians negatively and significantly.

Hypothesis 1a: Perception of procedural justice negatively and significantly affects the organizational silence of academics.

Hypothesis $1 \mathrm{~b}$ : The perception of interactional justice negatively and significantly affects the organizational silence of academics. Hypothesis 1c: Perception of distributive justice negatively and significantly affects the organizational silence of academics.

Hypothesis 2: The perception of organizational justice has a regulatory role in the organizational silence of academicians, and trust in the manager has a regulatory role. That is to say, as the trust in the administration with organizational justice increases, the organizational silence decreases. 


\section{Findings and discussion}

\section{Findings as a result of analysis}

The data obtained from the study participants were analyzed primarily for organizational justice and sub-telephone, and the means, standard deviations and correlations of these variables with each other for organizational silence and perception of trust in the manager. As a result, it is seen that organizational justice is negatively and moderately associated with organizational silence and positively and moderately associated with administrators' trust when considering the relationships between variables. Likewise, it is understood from the findings that organizational justice sub-dimensions are negatively associated with organizational silence and positively and moderately associated with trust in managers. In addition, trust in the manager has a moderately negative relationship with organizational silence.

\section{Hypothesis test results}

According to the results of the study, the hypothesis which is below were accepted;

H1: The perception of organizational justice affects the organizational silence of academicians negatively and significantly.

H1a: Perception of procedural justice negatively and significantly affects the organizational silence of academics.

H1b: The perception of interactional justice negatively and significantly affects the organizational silence of academics.

H1c: Perception of distributive justice negatively and significantly affects the organizational silence of academics.

$\mathrm{H} 2$ : The perception of organizational justice has a regulatory role in the organizational silence of academicians, and trust in the manager has a regulatory role.

\section{Discussing the findings with the literature}

When the research results are examined, the findings obtained from these analyses support the studies carried out before by considering the same variables. The current organizational justice and employee silence literature reveal a negative relationship between these two variables (Tan, 2014; Mirmohammadi \& Marefat, 2014). The findings are that there is a significant inverse relationship between organizational justice and employee silence. These findings are supported by the research results of Tan (2014) and Mirmohammadi and Marefat (2014), who stated that the decrease in the level of silence in the processes was affected by the perception of justice. In addition, organizations that employees trust in their managers will be more successful in achieving their goals and have better interpersonal results. That is, the feeling of trust enables organizations and managers to focus on longterm activities. Therefore, if managers can increase their relationship of trust with their employees, they can also increase employees' vocal behaviour. The right decisions to be taken by the organizations will positively affect the success. Involving employees in these decisions will also make it easier to present new ideas and suggestions.

\section{Conclusion, recommendation and limitations}

\section{Results of the article}

According to the results of this study model, organizational justice affects organizational silence negatively and statistically significant, but trust in the manager is positively and statistically significant. Similarly, while the sub-dimensions of organizational justice perception affect organizational silence negatively and statistically significant, it also affects trust in the manager positively and statistically significant. The analysis results of the primary model of the study determined that the perception of organizational justice directly affects organizational silence and that the trust in the leader plays a moderating role in the relationship between these two variables. According to the final working model results, organizational justice is considered harmful and moderate with organizational silence and positive and moderate with trust in the leader. Likewise, it is understood that organizational justice sub-dimensions are negative with organizational silence, positive and moderate with trust in the leader. In addition, trust in a leader has a moderately negative relationship with organizational silence. These findings state that academics with a high perception of justice will not behave in silence and express their opinions. So, the silent behaviour of the employees when the justice algorithms are formed and the feelings of trust in their leader increase. In short, trust in a leader makes organizational justice perception harmful and meaningful in organizational silence behaviour. In other words, high trust in a leader strengthens the negative relationship between organizational justice and organizational silence.

\section{Suggestions based on results}

Based on the results and analysis, academics can express themselves freely with an organizational climate designed for this purpose. Therefore, an organizational climate should be created, and communication channels should be reorganized so that academicians are supported in active participation and open their ideas and opinions openly. In this way, academicians' professional satisfaction levels are increased and evaluated more positively to university outputs. In addition, the following suggestions can be given that an increase in the perception of organizational justice in which the manager is trusted decreases organizational silence:

-to encourage creativity and creative offering,

-to create a rewarding system by the beliefs and ideas that give employees according to their performances,

-to give importance to work and committees in order to realize new and applied ideas of employees,

-to organize training courses on communication and management skills training for managers and employees.

\section{Limitations of the article}

The study has some limitations. The first is a cross-sectional study. Examining organizational silence with a longitudinal study and its interaction with organizational justice and the regulatory role of trust in leaders will reveal more reliable findings. In the future, different studies can be conducted by focusing on participant characteristics and many variables that may affect person perceptions. In addition, the results may vary according to the institutional cultures where the data are collected. Therefore, considering some cultural issues, the study can be repeated by changing the population and sample. 


\section{Giriş}

Tüm örgütler, son zamanlardaki telaşlı rekabet çağında maliyetlerini mümkün olan her türlü yolla düşürmek için büyük bir mücadele vermektedir. Bu maksatla örgütler inisiyatif ve değişimin varlığından dolayı sorumluluk almak, şiddetli rekabet sırasında proaktif olmak, müşteri beklentilerini daha yüksek düzeyde karşılamak ve daha kalite odaklı hareket etmek gibi çalışanlarından daha fazla talep ve beklenti oluşturmaktadırlar. Bu beklentilerin karşılanması için örgütlerin duyarlı bireylere ihtiyacı vardır. Ancak bazı çalışanlar, örgüt içinde hâkim olan herhangi bir konuda seslerini ve endişelerini dile getirememekte ve bu nedenle sessizliği tercih etmektedirler. Bir yandan, örgütlerin tetikte ve ifade gücüne sahip çalışanlara ihtiyacı varken öte yandan çalışanlar, endişelerine değer veren örgütleri ararlar. Sessizliğin olmaması nedeniyle, çalışanlarda ve örgütte daha iyi performans ve yüksek motivasyon olması muhtemeldir. Bununla birlikte, sessizlik kültürünü kırmak ve çalışanların seslerini yükseltebilecekleri kültürel ortamı geliştirmek, şu anda yöneticiler için ayrı bir çaba ve gayret gerektirmektedir. Morrison ve Milliken (2000), örgütsel sessizliği çalışanların hem örgüt yararına olabilecek fikirlerini hem de örgütteki problemlerle ilgili düşüncelerini söylemekten çekinmeleri, dile getirmemeleri olarak tanımlamışlardır. Örgütlerin refahı ve istikrarı için, sessizliğin başlıca nedenleri olan faktörleri vurgulamak çok önemlidir. Bunlar örgütsel sessizliğin ortaya çıkmasına bağlı faktörlerdir. Örgütsel sessizliğin başlıca nedenlerinden bazıları örgütsel politik becerilerin eksikliği, korku ve utanç, çalışma arkadaşları ve benzeri unsurlardır (Nielsen, 2003).

Araştırmanın öncelikli amacı, örgütsel adalet algısının yapısına odaklanıp olumlu örgütsel adalet algısının örgütsel sessizlik davranışında azalmaya nasıl yol açabileceğini göstermektir. Öte yandan, "örgütsel adalet" kavramı, çalışanların işyeri prosedürlerini, etkileşimleri ve sonuçlarını adil olarak algıladıkları ölçüde ifade edilir (Baldwin, 2006, s. 1). Örgütsel adalet algısı, çalışanların davranışlarının önemli göstergelerinden birisidir (Tan, 2014: 1191). Potansiyel olarak hem örgütler hem de çalışanlar için güçlü faydalar yaratabilir. Bu faydalar arasında daha fazla güven ve bağlllık, iyileştirilmiş iş performansı, daha yararlı vatandaşlık davranışları, iyileştirilmiş müşteri memnuniyeti ve azalan çatışma bulunmaktadır (Cropanzano, Bowen ve Gilliland, 2007, s. 34).

Araştırmanın sonraki bölümünde örgütsel adalet ile örgütsel sessizlik arasındaki ilişkide yöneticiye duyulan güvenin düzenleyici rolü incelenmiştir. Güvene dayalı yönetim anlayışı, iyi bireysel ve örgütsel sonuçlar elde etmede etkili olabilir. Yetkililer, güvenin insanlar, gruplar ve örgütler arasında iş birliğine yol açabileceğine inanmaktadırlar. Örgütler, insanlar ve gruplar arasında katılımı iyileştirmek ve bunların etkilerini kullanmak için yeni çözümler aramaya çalışmaktadır (Jones ve George, 1998). Tüm örgütsel ilişkiler güvene dayalı olarak kurulur. Örgüt yöneticilerinin ve çalışanlarının, güvenin, güveni yükseltmenin ve güvendeki rollerinin önemini dikkate almaları önemlidir (Fitzroy, 2007). Örgütteki reformlarda yöneticilerin ve liderlerin rolü büyük önem taşımaktadır. Başarılı geri bildirim ve gelişmiş örgütsel davranış gözlemi için, örgütteki ast-üst arasında yüksek düzeyde kişilerarası güvene ihtiyaç vardır (Bakiev, 2013).

Yöneticiye duyulan güvenin, örgütsel adaletin işyerinde örgütsel sessizlik düzeyi üzerindeki olumlu etkilerini artırmak suretiyle tampon bir etki yaptığı değerlendirilmektedir. Adalet algısı, günümüz çalışma ortamının tamamlayıcı bir yönü olarak kabul edilmektedir. Dolayısıyla, mevcut çalışma ile örgütsel adaletin örgütsel sessizlik üzerinde etkisinin olduğu ve yöneticiye duyulan güvenin de bu ilişkide düzenleyici (1lımlaştırıcı) rolü olduğu değerlendirilmektedir. Özellikle örgütlerin gelişimi ve değişimi anlamında örgütsel sessizliğin istenmeyen bir durum olduğundan hareketle çalışmanın akademisyenler özelinde yapılmasının manidar ve çok önemli olduğu değerlendirilmektedir. Zira akademisyenlerin bilimsel ve araştırmaya dayanan her türlü bilgi, belge, araştırma ve bunlara bağlı olarak düşüncelerini özgürce ifade edebilmeleri örgütlerin performansı ve gelişimi açısından çok değerlidir. Bu kapsamda çalışmada elde edilen bulgulara göre akademisyen (çalışan), üniversitede yönetici konumunda bulunanlar (yönetici), üniversitelere (örgütlere) tavsiyeler ile gelecekte konu hakkında çalışma yapacak araştırmacılara da önerilerde bulunulacaktır. Ayrıca, alan yazın incelendiğinde, örgütsel adalet ile çalışan sessizliği arasındaki ilişkide yöneticiye duyulan güvenin düzenleyici etkisi üzerine herhangi bir çalışmaya rastlanılmamıştır. Bu nedenle, bu çalışma bu araştırma boşluğunu doldurmayı taahhüt etmektedir.

\section{Literatür taraması}

Çalışmanın bu bölümünde örgütsel sessizlik, örgütsel adalet ve yöneticiye duyulan güven kavramsal açıdan irdelenmiş ve bu değişkenler arasındaki ilişkilere değinilmiştir. 


\section{Örgütsel sessizlik}

Çalışan sessizliği literatürde ilk olarak 1970 yılında sosyal bilimci Albert Hirchmann tarafından belirtilmiş ve daha sonra başka bilim adamları tarafından geliştirilmiştir (akt. Brinsfield Edwards ve Greenberg, 2009). İlk sessizlik tanımlarında "sessiz kalmanın sadakat göstermekle eşdeğer olduğunu" ve "endişeler dile getirilmediğinde her şeyin yolunda gittiği" varsayımlarına yer verilmiştir. Ancak bugün araştırmacılar, örgütlerde kronik bir sessizlik ortamının olması durumunda istenen olumlu örgütsel sonuçların elde edilmesinin zorluğundan bahsetmektedirler (Aylsworth, 2008). Çalışanlar sessiz kaldığında, örgütleriyle ilgili bazı bilgileri saklarlar. Bu bilgi nesnel verilere, bir fikir veya endişe gibi bazı öznel yargılara dayanabilir. Çalışan veya örgütsel sessizlik aynı zamanda bilinçli ve kasıtlıdır ve genellikle diğer bazı faktörler tarafından motive edilir (Radmard vd., 2014). Örgütsel sessizlikte odak nokta "bireyler neden ve hangi durumlarda sessiz kalmayı tercih ederler, neden ve hangi durumlarda seslerini çıkartırlar" sorusudur (Milliken ve Morrison, 2003a, s. 1566). Aslına bakılırsa örgütsel sessizlik araştırmaları odak noktası itibariyle iki ayrı alt başlık altında yani çalışan sessizliği ve çalışan sesliliği olarak çalışılmıştır (Morrison ve Milliken, 2000; Pinder ve Harlos 2001; Briensfield, 2009). Bu çalışmada da genel olarak örgütsel sessizlik kavramı ele alınmıştır.

Sessizlik, sesin olmamasıdır (Pinder ve Harlos, 2001). Örgüt içerisinde sessizlik, çalışanların çalıştıkları kurumla ilgili konularda bilişsel, duyuşsal ve davranışsal olarak üst yönetime değerlendirmelerini söylememeleridir (Pinder ve Harlos, 2001, s. 334-335). Bu değerlendirmelerini dile getirdiğinde yönetimin baskılarına maruz kalacağını düşünen çalışanların fikir ve düşüncelerini dile getirmemeleri sonucunda ortaya çıkan bu davranış topluluğu örgütsel sessizlik olarak yazında yerini almıştır (Morrison ve Milliken, 2000, s. 707). Çalışanlar örgütün belirli yönleri konusunda sessiz kalabilirler (Çınar, Karcıŏglu ve Alioğulları, 2013).

Teorisyenler örgütsel adaleti, iş tatmini veya iş tatmini eksikliğini öngörücü veya fikir ve sessizlik faktörleri olarak ifade etseler de, Morrison ve Milliken (2000, s. 706) bu değişkenleri örgütsel sessizliğin sonuçları olarak vurgulamışlardır. Sessizliğin temel kaynakları, üst düzey yöneticilerin olumsuz geri bildirimlerini içerir, mesajı görmezden gelirler, kaynağın güvenilirliğine saldırırlar. Örgütsel sessizlik altındaki çalışanlar gerçeklik hakkında bilgi taşırlar ancak belirli tehditler nedeniyle yöneticilerinin önünde sessiz kalmayı tercih ederler. İklimde hüküm süren sessizliğin olumsuz örgütsel sonuçlar üreteceği gözlemlenmiştir (Aylsworth. 2008).

Artan rekabet, müşteri beklentilerinin yüksek olması, sürekli değişimin bir sonucu olarak ortaya çıkan kalite nedeniyle örgütler, çalışanlarının yenilikçilik ve sorumluluk kabulüne dahil olmalarını beklemektedir. Günümüzde, hayatta kalmak için, örgütlerin çevresel zorluklara karşı iyi tepki vermelerine ihtiyaç vardır ve bilgiyi paylaşmaktan korkmadan kendi inançları ve ekiplerinin inançları için girişimlerde bulunmalıdır. Bu hususlar yetkilendirme ve açık iletişim kanallarına vurgu yapsa da çalışanların çoğu, örgütlerinin iletişim, bilgi ve bilgi paylaşımını desteklemediğini ve bu hususların değişim yönetimi planlarının başarısızlığının nedenleri olduğunu bildirmektedir (Vakola ve Bouradas, 2005). Yöneticinin sessizliğge karşı tutumu ve artan sessizlik bileşenleri olarak iletişim tarzlarının çalışanların iş tatmini üzerinde etkili olduğu da ortaya koyulmuştur (Fard ve Karimi, 2015: 219). Nitekim örgütsel sessizlik ne kadar kırılırsa, çalışanlar kendi görüşlerini sunma fırsatlarına sahip olabilmekte ve iş tatmini ve iş motivasyonları da o derece artmaktadır (Alkayış, 2015). Bu konuyu görmezden gelmek, olumsuz olaylara, hatta örgütün ölümüne yol açabilir. Bagheri ve arkadaşlarına (2012) göre, zaman geçtikçe örgütün sessizliği örgüt için düşük kaliteli işlere sebep olacaktır. Bu tür senaryolarda çalışanlar sadece güvenlerini kaybetmekle kalmaz, aynı zamanda özgüvenlerini de yitirir ve örgüt için faydalı çıtılar üretme konusunda zayıf kalırlar. Günümüzde artan rekabet, yüksek müşteri beklentileri ve kalite nedeniyle örgütler, çalışanlarının sorumluluk kabulü ve yeniliğe dahil olmasını beklemektedir. Ayrıca, örgütlerin hayatta kalabilmeleri için, çevresel zorluklara iyi tepki vermesine ve bilgiyi paylaşmaktan korkmayan ekiplere ihtiyaçları vardır.

Örgüt içerisinde yarattığı olumsuz durumlar nedeniyle sessizlik davranışının iki yönlü bazı etkileri olduğu vurgulanmıştır (Pinder ve Harlos, 2001, s. 338; Çakıcı, 2007, s. 148-149). Bu kapsamda örgütsel sessizliğin söz konusu etkileri; "kişileri ortak paydada birleştirebilir veya birbirinden uzaklaştırabilir; kişilerarası ilişkileri geliştirebilir veya koparabilir, bilgilerin edinilmesini sağlayabilir veya gizlenmesine neden olabilir; düşünceleri derinlemesine irdeleyebilir veya düşünmekten alıkoyabilir, olası bir durumu kişilerin onayladığını gösterebilir veya onaylamadığını belirtebilir" şeklinde sıralanabilir.

Alan yazında genel olarak örgütsel sessizliğin kabullenici, korumacı ve savunmacı olmak üzere üç boyutta incelendiği araştırmalar mevcuttur (Çakıc1, 2010; Durak, 2014; Park ve Keil, 2009; Van Dyne, Ang ve Botero, 2003). Bireylerin örgüt içerisinde bilinçli ve kasıtlı olarak sessiz kalması, sorunların çözümü için alternatifleri bilse bile çözüm konusunda isteksiz davranması anlamında kullanılan kabullenici sessizlik (Pinder ve Harlos, 2001); bireylerin örgüt içerisinde şahsi menfaatlerini korumak 
ve diğerleriyle ters düşmemek için sessiz kalmalarını ifade eden savunmacı sessizlik (Park \& Keil, 2009); diğer çalışanların ve örgütün menfaatlerini korumak için fikir ve düşüncelerin paylaşılmamasını ifade eden korumacı sessizlik (Van Dyne vd., 2003) olarak yapılan sınıflandırma alan yazında yerini almıştır. Bu çalışmada örgütsel sessizlik kavramı tek boyutlu olarak araştırmaya dahil edilmiştir.

\section{Örgütsel adalet}

Aslına bakıldığında adalet kavramı uygarlıklara, çağlara, toplumlara, kültürlere ve kişilere göre değişmektedir (Cropanzona ve Folger, 1998, s. 12). Adalet, eskiden beri süregelen, açıklanmaya çalışılan ve sayesinde güç kazanılacağı düşünülen bir kavram olmuştur. Örgütsel adalet terimi de, insan motivasyonunun adalet duygusundan etkilendiği gerçeğine dayanan John Stacey Adams'a (1965) dayanmaktadır. Çalışanlar, zaman yatırımına ve bir örgütteki yeteneklerine göre adalet davranışı beklerler. Örgütsel adalet, çalışanlar ve örgütler için güveni memnuniyet, bağlılık ve iş performansı gibi olumlu iyileştirmeler sağlayabilir (İşcan ve Sayın, 2010). Örgütsel adalet, çalışanların kendilerine ne kadar adil davranıldığına ilişkin algılarını ve bu algının örgütsel bağlılık ve memnuniyet gibi sonuçları nasıl etkilediğini açıklamaktadır (Greenberg, 1996). Öte yandan, örgütsel adalet eksikliği örgütler için sorunlu durumlara neden olmaktadır (Cropanzao ve Wright, 2003).

Örgüt içerisindeki sosyo-ekonomik alandaki değiş tokuşlar, çalışanların iş arkadaşlarıyla, yöneticileriyle ve örgütle olan ilişkileri onların örgütsel adalet algılarını oluşturmaktadır (Beugre, 1998: 351). Olumlu olarak algılanan bu davranışlar örgüt içerisinde, çalışanların da kendilerini değerli hissetmesi, örgüte ve yönetime karşı güven duyması gibi olumlu davranışlara yol açarken, olumsuz algılanan adalet duygusu da olumsuz davranışların gelişmesine sebep olmaktadır (Özmen vd., 2007, s. 19). Yönetimin aldığı kararların ve uygulamaların adil olduğunu algılayan çalışanların motivasyon ve performansları da olumlu yönde etkilenecektir (Koçel, 2014, s. 530).

Örgütsel adalet araştırmacılar tarafından çeşitli boyutlarda ele alınmıştır; örgütsel adalet kavramı ağırlıklı olarak başlarda dağıtımsal adalet ve prosedürel adalet olarak ele alınırken (Greenberg, 1987, s. 13), daha sonra etkileşimsel adalet boyutu da alan yazına kazandırılmıştır (Colquitt, 2001:392). Bu çalışmada da örgütsel adalet; dağıtımsal adalet, prosedürel adalet ve etkileşimsel adalet olmak üzere üç boyutuyla ele alınmıştır. Bu boyutların her birine aşağıda kısaca değinilmiştir.

Dağıtımsal adalet, bir bireyin örgütten aldığı sonuçların algılanan adaletini ifade eder. Çıktılar eşitlik, ihtiyaç veya katkı temelinde dağıtılabilir ve bireyler diğerleriyle kıyaslayarak dağıtımın adilliğini belirler (Alsalem ve Alhaiani, 2007). Bu tür adalet, dağıtılmakta olan sonuçların, eşitlik ilkesi adı verilen girdilerle orantılı olması gerektiğini ifade eder. Eşitlik kuramcılarına göre, bireyler, algılanan girdilerinin oranını, başvuran diğerininkiyle karşılaştırır. Oranlar eşitse, birey dağıtımcı adaleti algılar. Oranlar eşit değilse birey eşitsizliği algılayacaktır (Jawahar, 2002). Eşitlik teorisine atıfta bulunarak, çalışanlar adaleti sağlamak için işlerinin niteliğini veya miktarını değiştireceklerdir. Çalışanlar örgütte adaletin olduğunu düşündüğünde, kendi menfaatleri ile örgütün menfaatlerini dengelemekte çaba gösterecektir. Ek olarak, çalışanlara adil muamele edildiğinde, "kendi kısa vadeli bireysel çıkarlarını bir grubun veya örgütün çıkarlarına tabi kılmaya daha istekli olurlar" (McCain, Tsai, Bellino, 2010). Sonuçların dağıtımında algılanan adalet, işlerde memnuniyet yaratır ve bu nedenle örgütü iyileştirmek için çalışanlar sessiz kalmayarak görüşlerini ifade eder.

Prosedürel adalet, katılımcıların bir süreci düzenleyen kuralların ve prosedürlerin adilliğine ilişkin algılarını belirtmektedir (Nabatchi, Bingham ve Good, 2007). Dağıtımsal adalet, çalışanların aldığı tazminat miktarlarının algılanan adaleti anlamına gelirken; prosedür adaleti, bu miktarları belirlemek için takip edilen sürecin ve bu süreçte kullanılan araçların algılanan adaletidir (Folger ve Konovsky, 1989). Ayrıca, prosedür adaleti, dağıtım yollarını elde etmede adaletin bireysel olarak değerlendirilmesi anlamina da gelir (Tan, 2014).

Etkileşimsel adalet, kararların ve prosedürlerin temsili sırasında sergilenen kişilerarası davranışa ilişkin çalışanların algılarına odaklanır (Bies ve Moag, 1986). Yöneticilerin örgütsel faaliyetlerle ilgili (işlemsel ve dağıtımsal) işlemleri yerine getirirken çalışanların ve yöneticilerin karşılaştığı davranış ve tavırların özellikleri olarak tanımlanmaktadır (Liao ve Tai, 2006). Etkileşimsel adalet ayrıca kişilerarası ve bilgisel adaleti de içerir (Leventhal, 1980). Bir örgütün çalışanları, örgütlerinin prosedürlerinde, politikalarında, etkileşimlerinde ve dağıtım sistemlerinde adil olduğunu algılarlarsa olumlu davranışları ve üretkenliği yansıtırlar. Örgütsel adaleti geliştirmek, çalışanlardan daha iyi sonuçlar alınmasını sağlar (Usmani ve Jamal, 2013). Ayrıca, çalışan bağlılığını artırabilir ve çalışanların kuruma ait hissetmelerini sağlayabilir (Yeşil vd., 2020, s. 568). 


\section{Yöneticiye duyulan güven}

Örgütsel güven; örgütlenme, toplum entegrasyonu ve örgütlerde demokrasi yaratmak için temel ihtiyaç olarak ortaya çıkar. Günümüzde güven, geniş yönetim yelpazesinde önemli bir yapı olarak yaratılmaktadır (Horn-Nord, Paliszkiewicz, Koohang ve Gołuchowski, 2014). Örgütsel güven, kişilerin olumlu beklentilerini ve örgüt üyelerinin, kişilerarası güven ve kurumsal güven dahil olmak üzere yeterlilik, güvenilirlik ve yardımseverlik konusundaki beklentilerini ifade etmektedir (Mayer, Davis ve Schoorman, 1995). Kişilerarası güven, yanal güven ve dikey güven olarak ikiye ayrılır. Yanal güven, çalışanların birbirine olan güveni olarak tanımlanırken dikey güven, örgütteki çalışanlar ve yöneticiler arasındaki güvendir (Ellonene, Blomqvist ve Puumalainen, 2008).

Yeni dönemde, her örgütte çalışanların temel ihtiyaçlarına cevap vermek öncelikli olup, örgütteki çalışanların en önemli ihtiyaçlarından biri, kendi aralarında ve örgütte güven tesis etmektir. Yöneticilere yüksek düzeyde güven, düşük değerlendirme maliyetleri ve diğer kontrol mekanizmaları yaratır (Khanifar, Moghimi, Jandaghi ve Zarvandy, 2009). Yöneticilere güven, örgütsel beklentilere ve çalışanların örgüt yöneticilerinin ölçümlerine ilişkin algılarına ilişkin mesajlara dayalı olarak çalışanlar ve örgüt arasında kurulan ilişkiyi ifade etmektedir (Fard ve Karimi, 2015, s. 220). Güven, örgütlerin başarısında büyük önem taşımakta ve avantajlar yaratabilmektedir. Örgüt yöneticileri, güvenin karmaşıklığını çok boyutlu doğasını ve bunun örgütsel bağlılık, iş tatmini, örgütsel adalet, performans gibi değişkenler arasındaki ilişkilerin dinamikleri üzerindeki etkisinin farkında olmalıdır (SheikMohamed, Mohiadeen ve Anisa, 2012). Yöneticiye güven, bireysel performansın önemli bir öncülü olarak kabul edilir ve yöneticilik tarzı ve uygulamaları, yöneticilere olan güven ile bağlantılıdır (Dirks ve Ferrin, 2002). Bakıldığında güven, yöneticilikte meşruiyetin temelidir.

Güven, sosyal değişim (mübadele) ilişkisinin temelini oluşturur (Blau, 1964). Güven, değişim ortakları hakkındaki güven ve inançları karakterize eder. Bir örgütteki sosyal değişim, bir çalışan ile bir örgüt arasında gayri resmi bir sözleşme anlamına gelir ve bu sözleşmede, yönetici büyük ölçüde örgütü çalışana karşı temsil eder (Konovsky ve Pugh, 1994). Bu durumda, bir çalışanın yöneticisi ile olan ilişkisi kişiselleştirilmiş bir sosyal değişim biçimidir. Ayrıca, bu kişiselleştirilmiş sosyal değişim ilişkisi, çalışanın değişim ortağının (yani yöneticinin) uzun vadede yükümlülüklerini yerine getireceğine olan güvenine dayanmaktadır. Bu nedenle, bir çalışanın yönetici hakkında güçlü inançları ve güveni varsa, bu durum uzun vadede gönüllü davranışlar sergileyeceğine işaret eder (Organ, 1990).

Aynı zamanda güven, prosedürel ve dağıtımsal adalet arasındaki etkileşimsel ilişkinin anlaşılmasında kullanılan bir yapıdır. Yani güven düzeyi prosedürel adalete bağlı olarak gelişir ve dağıtımsal adalete göre de etkilileşir (Brockner, Siegel, Daly, Tyler ve Martin, 1997, s. 558).

Güven duygusu hem duygusal hem bilişsel olabilir. Duygusal güven, refahla ilgili endişeyi gösteren özel bir ilişkiyi yansitır ve bilişsel güven, güvenilirlik, bütünlük, adalet ve dürüstlük gibi sorunları yansitır (Dirks ve Ferrin, 2002; Wang, Tomlinson ve Noe, 2010; Yang ve Mossholder, 2010; Yang, Mossholder ve Peng, 2009). Duygusal güven, iki taraf arasında karşılıklı bir ilgi alışverişine dayanır (Dirks ve Ferrin, 2002; Yang vd., 2009), oysa bilişsel güven, takipçilerin tutumları ve bilgi, beceriler, yetenekler ve yeterlilik dahil liderin özellikleri hakkındaki algıları üzerinde bir etkiye sahiptir (Wang vd., 2010; Yang vd., 2009). McAllister (1995) güveni, yetkinlik ve sorumluluk alanlarındaki bilişsel güven ve bilişsel güvendeki merkezi unsurlarla ve etkileşime inanmaya dayanan duyuşsal güven olarak iki boyutlu bir değişken olarak ele alsa da liderlik ve güven literatürü, güvenin bu iki boyutunu birleştirmiştir. Liderlikle ilgili literatürdeki bazı ampirik çalışmalar, güveni tek boyutlu bir yapı olarak kavramsallaştırmıştır (Jung ve Avolio, 2000; Pillai vd., 1999; Podsakoff, MacKenzie, Moorman ve Fetter, 1990). Bu çalışmada da yöneticiye duyulan güven tek boyutlu olarak ele alınmıştır.

\section{Değişkenler arası ilişkiler ve hipotezler}

Örgütsel adalet kavramı çalışanların örgüt içerisindeki tutumlarını etkileyip sessiz kalmalarına neden olabilecek bir kavramdır. Alan yazında sessizlik kavramı ilk kez adalet kavramıla birlikte çalışılması 1980'li yıllara dayanmaktadır: Bu yıllarda çalışanların sessizlik davranışının sebepleri ile ilgili olarak örgütsel adalet kavramına odaklanılmıştır (Bagheri, Zarei ve Aeen, 2012, s. 48). Pinder ve Harlos (2001), çalışmalarında ilk kez bireysel düzeyde çalışanların adaletsizlik algılarının onları sessizliğge ittiğini ampirik bir çalışmayla ortaya koymuşlardır. Söz konusu çalışmanın sonuçlarına göre, çalışanların inançları doğrultusunda adaletsiz uygulamaların hâkim olduğu bir örgüt kültürü yapısı içinde sessizlik baş gösteren olumsuz davranışlardan birisidir. Alan yazına bakıldığında, örgütsel adalet ile örgütsel sessizlik arasında negatif yönlü anlamlı ilişkiler tespit eden çalışmalar mevcuttur (Özçınar, Demirel ve Özbezek, 2015, s. 150-171; Güngör ve Potuk, 2018; Karacaoğlu ve Cingöz, 2009; Günce, 2013; Güvenli, 2014; Önder, 2017; Milliken vd., 2003b, s. 1460). Meydan ve diğerleri de (2015), örgütsel etik değerlerin, çalışanların sessiz kalma davranışına etkisini ve bu etkide örgütsel adaletin aracılık rolünü incelemişler 
ve sonucunda, etik değerlerin örgütsel sessizlik davranışının bir açıklayıcısı olduğu ve adalet algısısın bu ilişkide aracılık etkisine sahip olduğu sonucuna ulaşmışlardır. Kısacası çalışanlar örgüt içinde adaletsizlik algılamalarıyla birlikte tepki göstermekten kaçını sessiz kalma eğilimine girerler ve bilgi ve düşüncelerini kasıtlı olarak paylaşmaktan kaçınırlar (Sözen, Yeloğlu ve Ateş, 2009, s. 406). Böylesi bir durumda, yani çalışanlar algıladıkları adaletsizlik karşısında kendilerini değersiz hisseder ve sessizleşebilir ve örgütlerine güvenmemeyi seçebilirler. Adaletli davranıldığı algısı oluştuğu durumlarda ise çalışanların sosyal etkileşimleri rol beklentilerinin ötesinde teşvik edilecek ve örgütlerine olan bağlılıkları da artacaktır (Karacaoğlu ve Cingöz, 2009, s. 701; Dabbagh, Esfahani ve Shahin, 2012). Bunun yanı sıra adaletsizliği oluşturan yöneticileri ile ilişkileri bozulduğundan bu da çalışanları sessiz kalmaya itebilir (Pinder ve Harlos, 2001, s. 359).

Aslında, sosyal değişim teorisine (Blau, 1964) göre, tüm ilişkiler örgütler içinde verme ve almaya dayanır. Ancak, bu değişimin dengesi her zaman eşit değildir. Sosyal değişim teorisi, çalışanların algılarına bağlı olarak başkalarıyla bir ilişki hakkında nasıl hissettiğini açıklar. Örgütsel adalet algısının olumlu olması örgütü ve kişileri birçok yararlı sonuca götürür- Bu faydalar arasında kararları desteklemek için yöneticilerin bağlllığ1 (Kim ve Mauborgne, 1991; Kim ve Mauborgne, 1993) artan güven ve bağlllik (Korsgaard, Schweiger ve Sapienza, 1995; Johnson, Korsgaard ve Sapienza, 2002; Aryee, Budhwar ve Chen, 2002); iş performansının artışı (Lavelle, Brockner, Konovsky, Price, Henley ve Vinekar, 2009; Charash and Spector, 2001) gelmektedir. Colquitt ve Greenberg (2003), çalışanların, kaynakların dağıtımında, örgütsel prosedürlerde ve yönetimin çalışanlara yönelik tutumunda adalet olduğuna inandıkları sürece örgütün yararına çalıştıklarını belirtmektedir. Dolayısıyla, çalışanların adaletsizlik algıları, geri çekilmelerine veya örgüt için olumsuz sonuçlar üretebilecek bazı tutumlara yol açabilir (Zoghbi-Manriquede-Lar, 2010). Adalet iklimi veya algılanan adalet, çalışanların konuşma veya sessiz kalma kararlarını etkileyebilir (Tulubas ve Celep, 2012). Thibaut ve Walker (1975)' in alan yazına kattığ1 prosedür adaleti kavramı (Blader ve Tyler, 2003, s. 747; Fortin, 2010, s. 98), karar alma ve bu kararların uygulanması süreçlerinde çalışanlara söz hakkı verilmesi ile ilgilidir (Steiner ve Bertolino, 2006, s. 2). Ayrıca, bu karar alınması sürecindeki tarafsız ve nesnel davranılmasını ifade eden prosedür adaleti, aynı zamanda güveni de esas alır (Demirel, 2009, s. 121). Yöneticilerin çalışanlarla örgütsel konularla ilgili bilgi paylaşımı yapmaları, konuşmaları ve geri bildirim sağlamaları hususlarında isteksizlik göstermelerinin de çalışanların yönetim ve örgüte karşı güven duyguları, motivasyon ve morallerini olumsuz olarak etkileyeceği ve sessiz kalmayı tercih edecekleri ileri sürülmektedir (Vokala ve Bouradas, 2005, s. 443).

Güven duygusunun gelişmesindeki önemli kaynaklardan birisi olumlu örgütsel adalet algısının oluşmasıdır. Yani, çalışanlar örgüt içindeki uygulamaların adilliğine ilişkin algılamaları olumlu ise yöneticilerine duydukları güven de olumludur (Konovsky ve Pugh, 1994, s. 658). Örgütsel adalet algisı ile güven duygusu arasında da pozitif yönlü anlamlı ilişkiler tespit eden çalışmalar mevcuttur (İşcan ve Sayın, 2010, s. 195-216; Demirkaya ve Kandemir, 2014, s. 263-279; Kılıçlar, 2011; Ülker, 2008; Demir, 2008). Çalışanlar yöneticilerin adil davrandığını algıladıklarında onlara daha çok güvenmektedirler. Çalışanların yöneticilerine güven duymaları, sessizlik davranışında bulunup bulunmamalarını da etkilemektedir. Yöneticiye duyulan güven, etkin bir iletişim ortamı kurulmasını sağlayabilir. Benzer şekilde ast-üst ilişkilerinin de sessizlik davranışı üzerinde etkisi olduğu düşünülmektedir. Özellikle hiyerarşik yapılardaki yukarı yönlü iletişim, ast-üst iletişiminden büyük oranda etkilenmektedir (Çakıcı, 2010, s. 30). Üst yönetimin davranışları, örgütsel sessizliğine sebep olan en önemli etmen olarak gösterilmektedir. Üst yönetimin davranışlarının çalışanlar arasında korku ve güvensizlik duygusuna yol açtığı durumda, sessizlik davranışının yaygın bir şekilde gözlemleneceği iddia edilmektedir (Vakola ve Bouradas, 2005, s. 444). Yöneticiye duyulan güvenin çalışların ses davranışları üzerinde etkili olduğu saptanmıştır (Çetin ve Güven, 2017). Binikos (2010) "Sessizliğin Sesleri: Örgütsel güven ve ıslık çalma kararları" çalışmasında "örgütsel güven" ile "sessiz kalma" arasında anlamlı ve olumsuz bir ilişki bulmuştur. Örgütsel güven arttıkça sessiz kalma olasılı̆̆ının azaldığını ve örgütte ıslık çalma ile başa çıkma kararının örgüt çalışanları arasında güvensizliğe yol açtığını belirtmiştir. Yöneticiye duyulan güven, örgütsel güvenin bir boyutu olduğu için sessiz kalma davranışı üzerinde bir etki yaratabileceği değerlendirilmektedir. Çalışanların düşünce ve önerilerini hiç çekinmeden söylemesinin çalıştığ1 yöneticilerine duydukları güven duygusuyla ilişkili olduğu (Gao, Janssen ve Shi, 2011, s. 791), ve yöneticisine güven duyan çalışanın sessizliği tercih etmediği (Ünler, 2015) vurgulanmaktadır. Bu sebeple, çalışanların yöneticilerine duydukları güvenin örgütsel adalet algılarının örgüt içindeki ses davranışların düzenleyici rol oynadığı düşünülmektedir.

Yukarıda bahsedilen tüm çalışmalar ve kuramlar ışığında aşağıdaki hipotezler geliştirilmiştir.

Hipotez 1: Örgütsel adalet algisı akademisyenlerin örgütsel sessizliğini negatif ve anlamlı olarak etkiler. 
Hipotez 1a: Prosedürel adalet algısı akademisyenlerin örgütsel sessizliğini negatif ve anlamlı olarak etkiler.

Hipotez 1b: Etkileşimsel adalet algısı akademisyenlerin örgütsel sessizliğini negatif ve anlamlı olarak etkiler.

Hipotez 1c: Dağıtımsal adalet algısı akademisyenlerin örgütsel sessizliğini negatif ve anlamlı olarak etkiler.

Hipotez 2: Örgütsel adalet algısının akademisyenlerin örgütsel sessizliğine etkisinde yöneticiye duyulan güvenin düzenleyici rolü vardır. Şöyle ki, örgütsel adaletin olduğu durumlarda yöneticiye duyulan güven arttıkça örgütsel sessizlikte azalma olur.

\section{Araştırmanın modeli}

Aşağıda verilen Şekil 1'de araştırmanın modeli ve hipotezleri sunulmuştur.

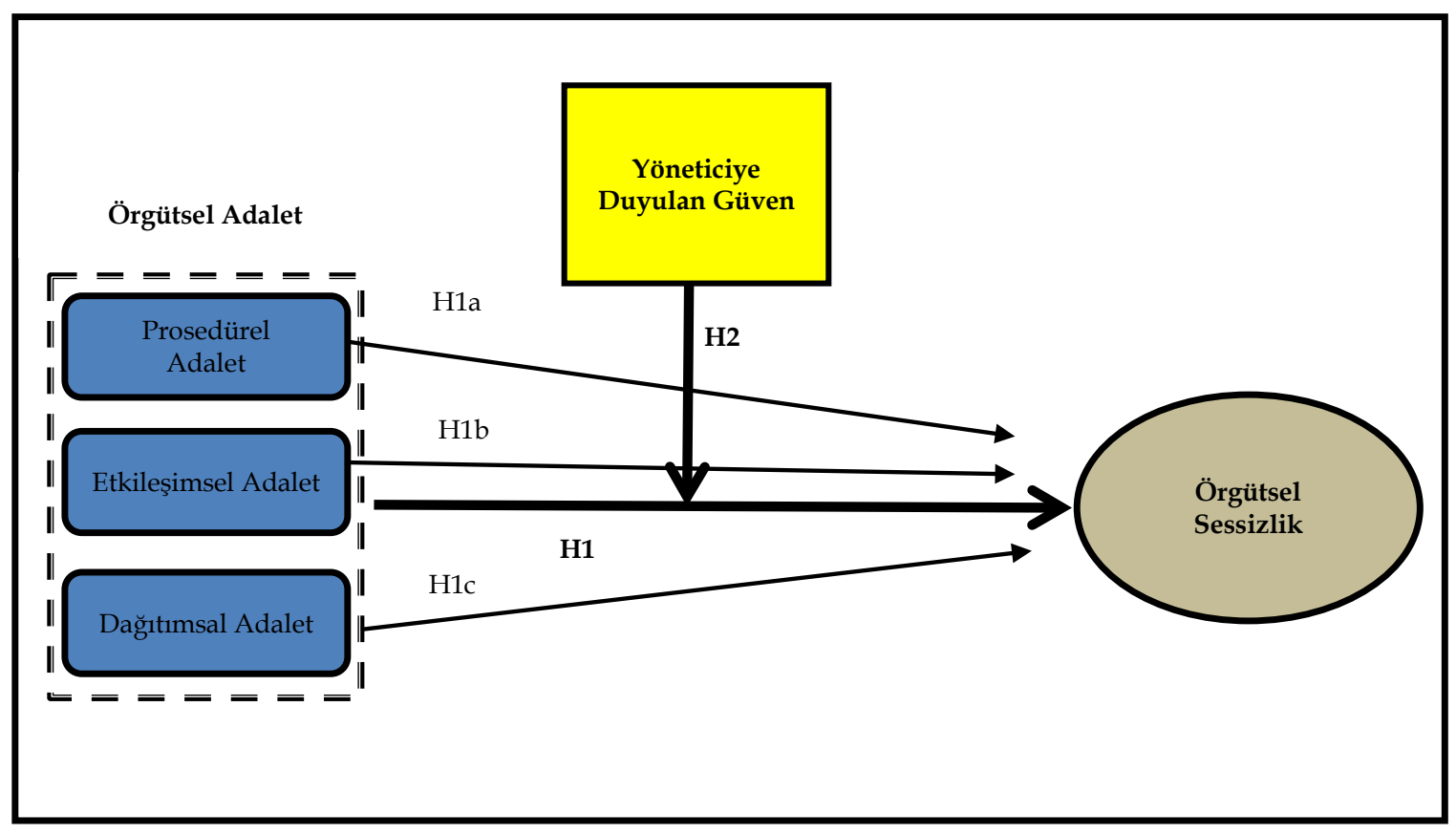

Şekil 1: Araştırmanın Modeli ve Geliştirilen Hipotezler

\section{Yöntem}

Araştırmada, korelasyonel araştırma modelinden faydalanılmıştır. Bu model, çalışmada kullanılan değişkenler arasındaki nedensel ilişkiyi ele almakta ve bu nedenle söz konusu ilişkilerin testinin yapılabileceği (Büyüköztürk, Çakmak, Akgün, Karadeniz ve Demirel, 2008) katılımcılardan değişkenlere ait ölçekler kullanılarak kolayda yöntem kullanılarak veriler toplanılmıştır. Analiz safhasında, her bir değişkene ait doğrulayıcı faktör analizi (DFA) yapısal eşitlik modeli (AMOS) kullanılarak yapılmıştır. Değişkenler arası ilişkileri ortaya koymak için korelâsyon analizi, hipotezlerin test etmek için hiyerarşik regresyon analizi yapılmıştır. Akademisyenlerin örgütsel adalet algılarının örgütsel sessizliklerine etkisinde yöneticiye duyulan güvenin düzenleyici rolünü test etmek için SPSS Process v3.5 Macro yazılımı ile Bootstrap yöntemini esas alan regresyon analizi yapılmıştır. Bootstrap yönteminin Baron ve Kenny'nin (1986) geleneksel yönteminden daha iyi sonuç verdiği öne sürülmektedir (Hayes, 2018).

\section{Araştırma katılımcıları}

$\mathrm{Bu}$ çalışmada genel olarak akademisyenlerin örgütsel adalet algılarının ve yöneticilerine duydukları güvenin görevleri esnasında örgütsel sessizlik davranışlarına olan etkileri araştırılacağından araştırma katılımcılarını Ankara'da bulunan üniversitelerde görev yapan akademisyenler oluşturmaktadır. Bu kapsamda anket formları evren içerisinde bulunan katılımcılara elektronik ve elle ulaştırılarak gönüllülük esasıyla cevaplamaları istenmiştir. Gönderilen ve dağıtılan 405 ölçek formunun 261'inden geri dönüş sağlanmıştır. Ancak yanlış veya eksik doldurulduğu anlaşılan 25 form kapsam dışında bırakılarak analizlere 236 katılımcıdan elde edilen verilerle devam edilmiştir. 
Araştırma katılımcılarının \%57'si (134) kadın, \%43'ü (102) erkektir. Yaş kategorisi açısından ise; \%9'u (21) 25 ve daha az yaşında iken, \%64'ü (151) 26-35 yaş aralığında, \%19'u (45) 36-45 yaş aralığında, \% 8'i (19) ise 46 yaş ve üstündedir. Ayrıca katılımcıların \%64'ü (152) evli, \%36'sı (84) ise bekârdır. Kurumda çalışma süreleri açısından bakıldığında, \%41'i (97) 5 yıl ve daha az, \%41'i (97) 6-10 yıl arası, \% 8'i (19) 1115 yıl arası, \% 7'si (16) 16-20 yıl arası ve \%3'ü (7) 21 yıl ve üzeri çalışma sürelerine sahiptir.

\section{Araştırmada kullanılan ölçekler}

Çalışmada kullanılan tüm ölçeklere ait bilgiler aşağıda olup ölçeklere ait yapısal eşitlik modeli kullanılarak yapılan DFA'lar neticesinde elde edilen uyum iyiliği değerleri Tablo-1'de toplu olarak verilmiştir. Ayrıca, çaıışmada ele alınan ölçeklerde araştırma katılımcılarının değerlendirildiği 5 li likert tipi derecelendirme ölçeği kullanılmıştır.

Örgütsel Sessizlik Ölçeği: Çalışmada örgütsel sessizlik algısını ölçmek için Çakıcı (2010) tarafından geliştirilen tek boyuttan ve dört maddeden oluşan form kullanılmıştır. Ölçek daha önceki çalışmalarda kullanıldığı için sadece DFA'ya tabi tutulmuştur. DFA neticesinde elde edilen uyum iyiliği değerleri $\left(\Delta x^{2}=2,239, \mathrm{sd}=2, \Delta x^{2} / \mathrm{sd}=1,120, \mathrm{RMSEA}=0,023, \mathrm{CFI}=0,996, \mathrm{GFI}=0,995, \mathrm{AGFI}=0,976\right)$ ölçeğin tek faktörlü yapısını doğrulamaktadır. Ölçeğin güvenirliği kapsamında Cronbach alfa değeri 0,90 olarak bulunmuştur.

Örgütsel Adalet Ölçeği: Çalışmada örgütsel adalet algısını ölçmek için Moorman (1991) tarafından geliştirilen ve Türkçeye Taşçığlu (2010) tarafından çevrilen ölçek kullanılmıştır. Ölçek; prosedürel, etkileşimsel ve dağıtımsal olmak üzere üç alt boyuttan ve 18 maddeden oluşmaktadır. Doğrulayıcı faktör analizi ölçeğin yapı geçerliğini sağlamak amacı ile yapılmaktadır ve çalışmada yapısal eşitlik modeli kullanılarak birincil düzey ve ikincil düzey çok faktörlü DFA uygulanmıştır. Yapılan DFA neticesinde hem birincil düzey çok değişkenli model için uyum iyiliği değerleri $\left(\Delta \chi^{2}=231,855, s d=125\right.$, $\left.\Delta x^{2} / \mathrm{sd}=1,855, \mathrm{RMSEA}=0,060, \mathrm{CFI}=0,960, \mathrm{GFI}=0,901, \mathrm{AGFI}=0,865\right)$, hem de ikincil düzey çok değişkenli model uyum iyiliği değerleri $\left(\Delta \chi^{2}=218,321\right.$, sd $=123, \Delta x^{2} / s d=1,775$, RMSEA= 0,057 , CFI= $0,964, \mathrm{GFI}=0,906, \mathrm{AGFI}=0,869)$ kabul edilebilir sınırlar içerisinde olduğundan örgütsel davranış bağımsız değişkenini çalışmada alt boyutlar ve genel anlamda tek boyutlu olarak kullanabilmek mümkün hale gelmiştir. Ölçeğin güvenilirliği kapsamında Cronbach alfa değerleri alt boyutlar bazında; prosedürel adalet için 0,87 , etkileşimsel adalet için 0,90 , dağıtımsal adalet için 0,82 ve genel olarak ise $0,91^{\prime}$ dir.

Yöneticiye Duyulan Güven Ölçeği: Çalışmada, Nyhan ve Marlowe'un (1997) geliştirilen ve 5 madde tek boyuttan oluşan ölçek formu kullanılmıştır. Ölçeğin Türkçeye uyarlaması Demircan (2003) tarafından yapılmıştır. Ölçek daha önceki çalışmalarda kullanıldığı için yapısal eşitlik modelinden istifade edilerek tek faktörlü DFA uygulanmıştır. Yapılan tek faktörlü DFA neticesinde uyum iyiliği değerlerinin $\left(\Delta \chi^{2}=4,471, s d=3, \Delta x^{2} / s d=1,490\right.$, RMSEA $=0,046$, CFI = 0,999, GFI= 0,992, AGFI=0,962) kabul edilebilir sinurlar dâhilinde olduğu gözlemlenmiştir. Ölçeğin güvenirliği kapsamında Cronbach alfa değeri 0,94 olarak tespit edilmiştir.

Tablo 1: DFA Neticesinde Ölçeklere Ait Uyum İyiliği Değerleri

\begin{tabular}{|c|c|c|c|c|c|c|c|}
\hline & $\Delta x^{2}$ & sd & $\begin{array}{c}\Delta \chi^{2} / s d \\
<5\end{array}$ & $\begin{array}{c}\text { RMSEA } \\
<.08\end{array}$ & $\begin{array}{l}\text { CFI } \\
>, 90\end{array}$ & $\begin{array}{l}\text { GFI } \\
>.85\end{array}$ & $\begin{array}{l}\text { AGFI } \\
>.85\end{array}$ \\
\hline $\begin{array}{l}\text { Örgütsel Sessizlik } \\
\text { (Tek Faktörlü Model) }\end{array}$ & 2,239 & 2 & 1,120 & 0,023 & 0,996 & 0,995 & 0,976 \\
\hline $\begin{array}{l}\text { Örgütsel Adalet } \\
\text { (1'inci Düzey Çok Faktörlü Model) }\end{array}$ & 231,855 & 125 & 1,855 & 0,060 & 0,960 & 0,901 & 0,865 \\
\hline $\begin{array}{l}\text { Örgütsel Adalet } \\
\text { (2'nci Düzey Çok Faktörlü Model) }\end{array}$ & 218,321 & 123 & 1,775 & 0,057 & 0,964 & 0,906 & 0,869 \\
\hline Yöneticiye Duyulan Güven & 4,471 & 3 & 1,490 & 0,046 & 0,999 & 0,992 & 0,962 \\
\hline
\end{tabular}

Not: Tüm uyum iyiliği değerleri kabul edilebilir sınırlar içerisindedir. 


\section{Bulgular}

Araştırmaya katılanlarından elde edilen veriler doğrultusunda öncelikle örgütsel adalet ve alt boyutları ile örgütsel sessizlik ve yöneticiye duyulan güven algısına yönelik ortalamalara, standart sapmalara ve söz konusu değişkenlerin birbirleri ile olan korelasyonlarına bakılmıştır. Tablo 2'de analiz sonuçları görülmektedir.

Tablo 2: Ortalama, Standart Sapma ve Değişkenler Arası Korelasyon Değerleri

\begin{tabular}{|c|c|c|c|c|c|c|c|c|}
\hline & Ort. & Ss. & ÖA_T & $\mathbf{P A}$ & EA & $\overline{\text { DA }}$ & ÖS & YDG \\
\hline Örgütsel Adalet (ÖA_T) & 3,2521 & 682 & $(0,91)$ & & & & & \\
\hline Prosedürel Adalet (PA) & 3,0875 & ,758 &, $830^{* *}$ & $(0,87)$ & & & & \\
\hline Etkileşimsel Adalet (EA) & 3,6189 & ,755 & $808^{*+}$ &, $534^{* *}$ & $(0,90)$ & & & \\
\hline Dağıtımsal Adalet (DA) & 3,0525 & 1,036 &, $805^{* *}$ & $479^{* *}$ & $491^{* *}$ & $(0,82)$ & & \\
\hline Örgütsel Sessizlik (ÖS) & 1,9625 & 862 &,$- 669^{* *}$ &,$- 532^{* *}$ &,$- 575^{* *}$ &,$- 534^{* *}$ & $(0,90)$ & \\
\hline $\begin{array}{l}\text { Yöneticiye Duyulan Güven } \\
\text { (YDG) }\end{array}$ & 3,6246 & ,882 & $637^{* *}$ & $457^{* *}$ & $698^{* *}$ & $440^{* *}$ &,$- 460^{* *}$ & $(0,94)$ \\
\hline
\end{tabular}

${ }^{*} \mathrm{p}<, 005,{ }^{* *} \mathrm{p}<, 001$, Not: Cronbach Alfa güvenirlik katsayıları parantez içinde verilmiştir.

Tablo 2 'de değişkenler arasındaki ilişkiler bakıldığında örgütsel adaletin (ÖA_T) örgütsel sessizlik ile negatif ve orta düzeyde $(\mathrm{r}=-0,669, \mathrm{p}<.01)$ ve yöneticiye duyulan güven ile ise pozitif ve orta düzeyde $(\mathrm{r}=0,637, \mathrm{p}<.01)$ ilişkili olduğu görülmektedir. Aynı şekilde örgütsel adalet alt boyutlarının da örgütsel sessizlik ile negatif, yöneticiye duyulan güven ile de pozitif ve orta düzeyde ilişkili olduğu Tablo.2'deki bulgulardan anlaşılmaktadır. Ayrıca yöneticiye duyulan güvenin de örgütsel sessizlik ile orta düzeyde negatif $(r=-0,460, p<.01)$ ilişkisi vardır. Korelasyon analizleri neticesinde örgütsel adalet değişkeninin alt boyutları ile ilgili korelasyon verileri dikkate alındığında ölçeğin yakınsak ve uzaksak geçerliğinin olduğu söylenebilmektedir. Bu da ölçeğin yapı geçerliğinin sağlanması için destekleyici bir bulgudur.

Çalışmada, örgütsel adaletin akademisyenlerin örgütsel sessizlik davranışlarına olan etkilerini ölçmek ve geliştirilen hipotezleri test etmek için hiyerarşik regresyon analizleri yapılmıştır. Söz konusu analizlerde demografik değişkenlerin etkilerini kontrol altına almak maksadıyla ilk aşamada söz konusu demografik değişkenler, daha sonraki aşamada ise bağımsız değişken olan örgütsel adalet değişkeni ve alt boyutları modele dâhil edilerek, bağımlı değişken olan örgütsel sessizlik üzerindeki etkilerine bakılmıştır. Yapılan regresyon analizlerine ait sonuçlar Tablo 3'tedir.

Tablo 3: Örgütsel Sessizliği Yordayan Örgütsel Adaletin Hiyerarşik Regresyon Analiz Sonuçları

\begin{tabular}{|c|c|c|}
\hline \multirow{2}{*}{ Bağımsız Değişkenler } & \multicolumn{2}{|c|}{ Örgütsel Sessizlik (ÖS) } \\
\hline & $\beta$ & $\Delta \mathbf{R}^{2}$ \\
\hline Demografik Değişkenler & & ,022 \\
\hline Cinsiyet & 041 & \\
\hline Yaş & 106 & \\
\hline Medeni Durum &,- 206 & \\
\hline Çalışma Süresi &,- 145 & \\
\hline$\Delta \mathbf{F}$ & \multicolumn{2}{|c|}{841} \\
\hline 2. Örgütsel Adalet (ÖA_T) &,$- 855^{\star *}$ & 435 \\
\hline Prosedürel Adalet (PA) &,$- 613^{* *}$ & ,278 \\
\hline Etkileşimsel Adalet (EA) &,$- 648^{* *}$ & ,315 \\
\hline Dağıtımsal Adalet (DA) &,$- 441^{* *}$ & ,270 \\
\hline$\Delta \mathbf{F}$ & \multicolumn{2}{|c|}{$182,605^{* *}$} \\
\hline
\end{tabular}

${ }^{*} \mathrm{p}<0,05{ }^{* *} \mathrm{p}<0,01$ 
Tablo 3'te, örgütsel sessizlik genel olarak ve tek tek araştırmada ele alınan demografik değişkenler (cinsiyet, yaş, medeni durum, çalışma süresi) tarafından anlamlı olarak yordanmamaktadır. Ayrıca analiz neticesinde, örgütsel adaletin genel olarak (ÖA_T: $\beta=-0,855, p<0,01)$ ve alt boyutlar bazında (PA: $\beta=-0,613$, EA: $\beta=-0,648, \mathrm{DA}: \beta=-0,441, \mathrm{p}<0,01)$ örgütsel sessizliği negatif ve anlamlı olarak yordadığı tespit edilmiştir. Yine bulgulardan örgütsel sessizliğin toplam varyansının $\% 43,5^{\prime}$ inin $\left(\Delta R^{2}=\right.$ 0,435, p<0,01) örgütsel adalet tarafından açıklandığı söylenebilir. Bu bulgular, akademisyenlerin örgütlerine yönelik adalet algılarının yüksek olmasının onları örgüt içerisinde sessiz kalmamaya ve düşüncelerini herhangi bir endişeye bağlı kalmadan açıklamaya sevk edebileceğine işaret etmektedir. Söz konusu bu bulgular ve değerlendirmeler çalışmada ele alınan H1 hipotezi ile tüm alt hipotezlerini desteklemektedir.

Örgütsel adalet algısının örgütsel sessizlik davranışı üzerindeki etkisinde yöneticiye duyulan güvenin düzenleyici rolüne ilişkin analizler SPSS Process v3.5 Macro ile yapılmıştır. Bulgular Tablo 4'te görülmektedir.

Tablo 4: Yöneticiye Duyulan Güvenin Düzenleyicilik Rolüne İlişkin Model Özeti

\begin{tabular}{|c|c|c|c|c|c|c|}
\hline \multicolumn{7}{|c|}{ Model Özeti } \\
\hline $\mathbf{R}$ & $\mathbf{R}^{2}$ & Std. Hata & F & df1 & df2 & $\mathbf{p}$ \\
\hline 6837 & 4674 & 4017 & 67,8645 & 3,0000 & 232,0000 & ,0000 \\
\hline \multicolumn{7}{|c|}{ Model } \\
\hline Değişkenler & $\beta$ & Std. Hata & $t$ & $\mathbf{p}$ & LLCI & ULCI \\
\hline Sabit & 2,0342 & ,0484 & 41,9872 & ,0000 & 1,9387 & 2,1296 \\
\hline ÖA_T &,- 5197 & ,0544 & $-9,5606$ & ,0000 &,- 6268 &,- 4126 \\
\hline YDG & -1927 & ,0557 & $-1,6651$ & ,0372 &,- 2024 &,- 0170 \\
\hline Int_1 &,- 1131 & ,0401 & $-2,8223$ & ,0052 & -1920 &,- 0341 \\
\hline Düşük &,- 4066 & ,0727 & $-5,5949$ & ,0000 &,- 5497 &,- 2634 \\
\hline Orta &,- 5197 & ,0544 & $-9,5606$ & ,0000 &,- 6268 &,- 4126 \\
\hline Yüksek &,- 6328 & ,0620 & $-10,2113$ & ,0000 &,- 7548 &,- 5107 \\
\hline \multirow{2}{*}{ ÖA_TxYDG } & $\Delta \mathbf{R}^{2}$ & F & df1 & df2 & $\mathrm{p}$ & \\
\hline & ,0183 & 7,9652 & 1,0000 & 232,0000 &, 0052 & \\
\hline
\end{tabular}

ÖA_T=Örgütsel Adalet, YDG=Yöneticiye Duyulan Güven, Int_1=Etkileşimsel Etki,

LLCI=Lower Level of Confidence Interval, ULCI=Upper Level of Confidence

Yöneticiye duyulan güvenin düzenleyici rolünü analiz etmek için oluşturulan ve Tablo 4'te gösterilen regresyon modelinin istatistiksel olarak anlamlı olduğu görülmektedir $\left(R=0,6837, R^{2}=0,4674, F=\right.$ $67,8645, p<, 01)$. Yine Tablo.4'ten, etkileşimsel etkinin (örgütsel adalet $x$ yöneticiye duyulan güven) anlamlı ve pozitif bir şekilde örgütsel sessizlik davranışını yordadığı $(\beta=-0,1131, t=-2,822, p<.01$, CI $[-0,1920 ;-0,0341])$ ve etkileşimsel etki yaratan değişkenin modele girmesi ile $\mathrm{R}^{2}$ nin $\% 1,83$ arttığ ve bu artışın anlamlı olduğu $\left(\Delta \mathrm{R}^{2}=0,0183, \mathrm{~F}=7,9652, \mathrm{p}<, 01\right)$ anlaşılmaktadır. Yani yöneticiye duyulan güven, örgütsel adalet algısının örgütsel sessizlik davranışına etkisinde $\% 1,83^{\prime} l u ̈ k$ ilave bir varyansı açıklamaktadır. Bu sonuç, yöneticiye duyulan güvenin örgütsel adalet algısı ile örgütsel sessizlik davranışı arasında düzenleyici rolü olduğunu ve çalışmada geliştirilen Hipotez 2' nin desteklendiğini göstermektedir, analizlerde elde edilen bulgular ışı̆̆ında Hipotez 2 kabul edilmektedir

Örgütsel adalet ile yöneticiye duyulan güvenin etkileşiminin büyüklüğünü ve yönünü belirlemek için, düşük, orta ve yüksek düzeydeki yöneticiye duyulan güven durumlarında, örgütsel adalet algısının örgütsel sessizlik davranışı üzerindeki etkisi grafiksel olarak Şekil 2'de gösterilmiştir. 


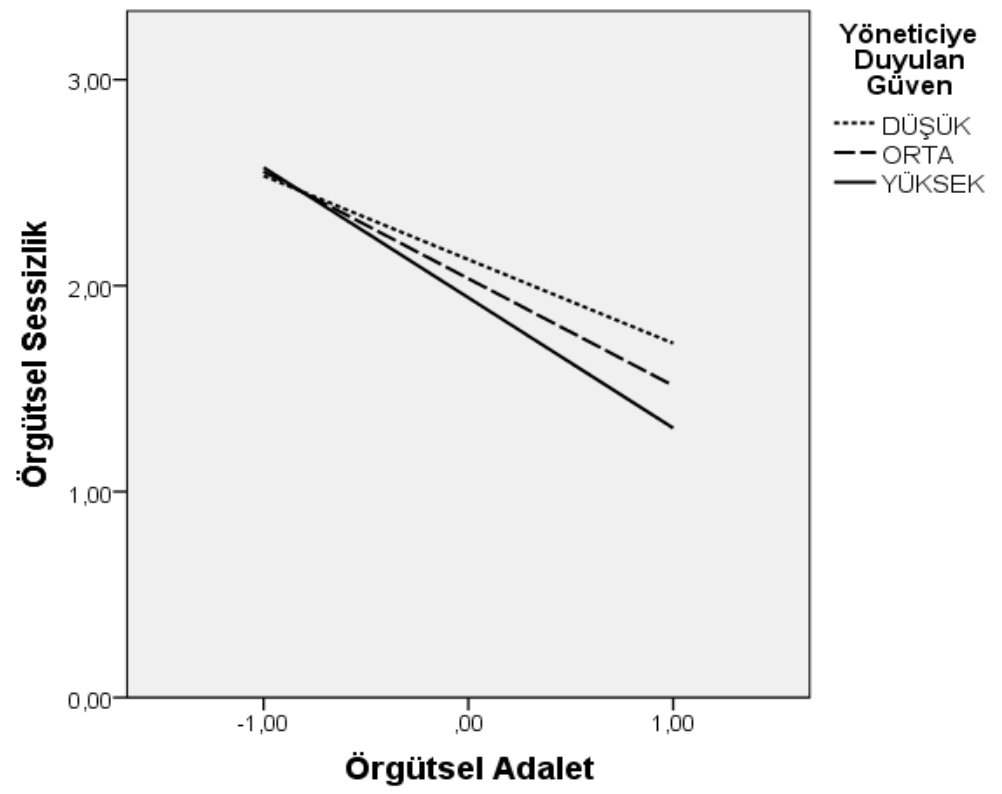

Şekil 2: Yöneticiye Duyulan Güvenin Düzenleyici Etkisi

Şekil 2'den ve Tablo 4'ten de görüldüğü üzere, yöneticiye duyulan güvenin düşük $(\beta=-0,4066, t=-$ $5,5949, \mathrm{p}<, 01)$, orta $(\beta=-0,5197, \mathrm{t}=-9,5606, \mathrm{p}<, 01)$ ve yüksek $(\beta=-0,5197, \mathrm{t}=-9,5606, \mathrm{p}<, 01)$ olduğu durumda örgütsel adalet algısı ile örgütsel sessizlik davranışı arasındaki etki negatif ve anlamlıdır. Yani örgütsel adalet algısının olduğu bir ortamda yöneticiye duyulan güven arttıkça akademisyenlerin örgütsel sessizlik davranışlarında da azalma olduğu söylenebilir.

\section{Sonuç ve öneriler}

Çalışanların, örgütteki kazanımların dağıtımı, kullanılan yöntem ve süreçler ile ilgili uygulamaların adil olduğuna dair algılamaları onları motive ederek fikir ve görüşlerini açıkça ifade edebilmelerini sağlamaktadır. Başka bir ifadeyle, yönetimin sergilediği etik ve adil davranışlar, çalışanların olumsuzlukla karşılaşma konusundaki korkularını azaltarak işle ilgili sorunlar hakkında konuşabilmeleri için onları teşvik edecektir. Aksi takdirde çalışanlarda oluşacak sessizlik davranışı, örgütler için son derece zararlıdır ve çalışanlar arasında diğer istenmeyen davranışlar gösteren bir memnuniyetsizlik düzeyinin artmasına neden olur (Colquitt ve Greenberg, 2003). Bu çalışma, sessizlik davranışın azaltmada örgütsel adalet algısının önemini ve bu ilişkide, yöneticiye duyulan güvenin düzenleyici rolünün irdelenmesi maksadıyla yapılmış ve yazına katkı sağlayacağı düşünülmektedir.

Araştırmanın ana modelinin analiz sonuçları, örgütsel adalet algısının örgütsel sessizlik üzerinde doğrudan etkisi olduğunu ve yöneticiye duyulan güvenin bu iki değişken arasındaki ilişkide düzenleyici (ılımlaştırıcı) rol oynadığını göstermiştir. Nihai çalışma modelinin sonuçlarına göre, örgütsel adaletin örgütsel sessizlik ile negatif ve orta düzeyde ve yöneticiye duyulan güven ile ise pozitif ve orta düzeyde ilişkili olduğu görülmektedir. Aynı şekilde örgütsel adalet alt boyutlarının da örgütsel sessizlik ile negatif, yöneticiye duyulan güven ile de pozitif ve orta düzeyde ilişkili olduğu bulgulardan anlaşılmaktadır. Ayrıca yöneticiye duyulan güvenin de örgütsel sessizlik ile orta düzeyde negatif ilişkisi vardır. Bu bulgular, adalet algısının yüksek olduğu durumlarda akademisyenlerin sessizlik davranışı göstermeyeceğini, fikirlerini açıkça beyan edebileceğine işaret etmektedir. Olumlu adalet algilarının oluştuğu durumlarda ve yöneticilerine olan güven duyguları da arttığında çalışanların sessizlik davranışlarında da azalma olacağını göstermektedir. Kısacası, yöneticiye duyulan güven, örgütsel adalet algısının örgütsel sessizlik davranışı üzerindeki negatif ve anlamlı etkisini güçlendirmektedir. Bir başka ifadeyle yöneticiye duyulan güvenin yüksek olması örgütsel adalet ile örgütsel sessizlik arasındaki negatif ilişkiyi güçlendirmektedir. Yöneticisine güvenen bir çalışan, adalet algısı yükseldiği zamanki sessizlik davranışındaki azalış, yöneticisine daha az güvenen çalışana göre daha az olmaktadır. Şöyle ki; örgütsel adaletin olduğu algısının yanında eğer akademisyenler yöneticilerine de güven duyuyorsa örgüt içerisinde sesiz kalmayıp her anlamda ve özellikle örgütün gelişimi ve yararına olması açısından düşüncelerini ortaya koyması daha muhtemel olacaktır. Bu kapsamda, çalışmaya ilişkin hipotezlerin tamamı desteklenmiştir.

Değişkenler arası ilişkilerde bahsedilen çalışmalarla kıyaslandığında bu çalışmanın analizlerinden elde edilen bulgular daha önce aynı konudaki çalışmalarla tutarlı ve sonuçlarını destekler niteliktedir. Mevcut örgütsel adalet ve çalışan sessizliği literatürü bu iki değişken arasında negatif bir ilişki olduğunu ortaya koymaktadır (Tan, 2014; Mirmohammadi ve Marefat, 2014). Bu iki kavram, yalnızca 
sosyal ortamlarda birbirini etkileyen karmaşık fenomenlerdir. Bulgular örgütsel adalet ile çalışan sessizliği arasında anlamlı ters bir ilişki olduğunu göstermiştir. Bu bulgular, örgütsel gelir dağılımı gibi konularda ve bu karar verilirken izlenen süreçler ve örgütsel gelirlerin dağılımı gibi süreçlerde sessizlik düzeyindeki azalmanın adalet algısından etkilendiğini belirten Tan (2014) ile Mirmohammadi ve Marefat'ın (2014) araştırma sonuçlarını desteklemektedir. Ayrıca, entegrasyonun en önemli faktörlerinden biri olarak çalışanların yöneticilerine güven duyması morallerinin yükselmesini ve dinamiklerin olumlu etkilenmesini sağlayacağı değerlendirilmektedir. Çalışanların yöneticilerine güven duyduğu örgütler, hedeflerini gerçekleştirirken daha başarılı olacak ve kişiler arası daha tutarlı sonuçlar doğacaktır. Şöyle ki güven duygusu, örgütlerin ve yöneticilerin uzun dönemli faaliyetlere odaklanmasını sağlar. Bu nedenle, yöneticiler çalışanlarıyla aralarındaki güven ilişkilerini artırabilirse, çalışanların ses davranışlarını da artırabilecektir. Örgüt içerisinde alınacak doğru kararlar başarıyı da olumlu yönde etkileyecektir. Bu kararlara çalışanların dahil edilmesi, yeni fikir ve önerilerin sunulmasını da kolaylaştıracaktır.

Örgütsel sessizlik, ceza korkusu ve fikirlerin küçümsenmesi, yöneticinin çalışanlara olan inancının olmaması veya iş durumunu tehlikeye atma korkusu gibi nedenlerle örgüt içinde çalışanların fikir eksikliği anlamında kullanılmaktadır. Örgütsel sessizlik; yenilikçiliğe, örgütsel değişimlere, sürekli iyileştirmeye, uygun geri bildirimlere, örgütsel bilgi yönetimine, örgütsel hataların iyileştirilmesine, çalışanların iç tatmini ve çalışanların doğru kararlarına engel olarak tehlikeli bir olgu haline gelmektedir. Örgütlerin önemli sorunlarından birisi, çoğu örgütün çalışanlarının sessizliğini önemsemesi ve bu koşullarda karar alma ve yenilik yaratma kalitesinin ve örgütün uzun vadeli ve stratejik hedeflerine ulaşmasının azalmasıdır. Ayrıca, olumsuz geribildirimden kaçınarak örgütsel sessizlik, örgütsel gelişimi ve değişiklikleri, memnuniyeti ve iş motivasyonunu önleyebilir.

Bazen çalışanlar sesini yükseltir ve fikirlerini aktarırken, bazı koşullarda da sessiz kalırlar. Akademisyenler gerek akademik çevre içerisindeki konumlarını koruyabilmek gerekse akademik unvanlarda ilerleyebilmek ve saygınlık kazanabilmek adına mevcut durumdaki işleyişi bozabilecek fikirlerini beyan etmekten kaçınabilirler. Bunun yanı sıra üniversite yönetimiyle (rektör, dekan, bölüm başkanları vb.) herhangi bir problem yaşamamak için duruma ters düşen düşüncelerini paylaşmayabilirler. Örneğin, üniversitelerde yapılan rektörlük seçimleri sırasında herhangi bir beklenti içerisindeyken (kadro, idari görev beklentisi gibi) veya gruplaşmaların etkisiyle dışlanmamak çabasıyla akademisyenler kişilik özelliklerini yansıtmayan genel eğilimden yana davranabilirler. Üniversitelerin diş çevreleri daha çeşitli hale geldikçe, içlerindeki çevre ve iletişim süreçleri de daha karmaşık ve etkileşimli hale gelmektedir. Aslında akademisyenler yönetim tarafından iş sorunlarını ele almak ve çözmek için zengin bir geri bildirim kaynağı olarak kullanılabilirler. Zorlu ortama yanıt vermeyi tercih eden, bilgi paylaşımından endişe duymayan akademisyenler hem kendileri hem de üniversiteleri için daha faydalı olacaktır. Bu tür çalışanlar örgüt için bir nimet ve değerli varlık olarak kabul edilir. Bu çalışma, akademisyenlerin iş sorumluluklarının ve görevlerinin ötesinde, işlerine ve örgütsel gelişimlerine yönelik ekstra çaba sarf etme niyetlerinin, kayıtsız ve sessiz (örgütsel sessizlik) tutumlarından nasıl olumsuz etkilenebileceğini ortaya koymaktadır. Ancak, akademisyenlere adil davranılacağına dair güven nedeniyle, etkili sessizlik çözümü artırabilir. Bu güveni oluşturamayan üniversitelerdeki sınırsız ve keyfi yetki kullanımının, akademisyenleri örgütsel çıkarlardan çok kişisel çıkarları korumaya itebileceği unutulmamalıdır.

Üniversitelerin öncelikli amacı güçlü bir akademik kadroyla öğrencileri yetiştirip topluma kazandırmaktır. Mezun öğrencilerin gerekli donanıma sahip olabilmesi için akademisyenlerin de yüksek performansa sahip olması gerekmektedir. Akademisyenler eğitimci olmalarının yanı sıra idari görevlerde de yer almaktadırlar. Her geçen gün sayısı artan vakıf ve devlet üniversiteleri düşünüldüğünde oluşan rekabet ortamında daha iyi çıktılara ulaşabilmek için üniversite yönetimlerinin sahip olduğu akademik kadronun örgütsel çıtılara etkisinin göz ardı edilmemesi gerekir. Akademisyenlerin olumlu örgütsel davranış sergilemelerinin sebeplerinden birisi de yönetimlerine karşı olumlu adalet algılarıdır. Akademisyenlerin adalet algılarını yönlendiren birçok etken olabilir; yöneticilerin tutum ve davranısları, örgütsel politikalar, performans değerleme yöntemleri, ödüllendirme ve cezalandırma kıstasları vb. gibi, yani bu algı birçok şeyden etkilendiği gibi birçok şeyi de etkileyebilir. Burada önemli olan akademisyenlerin adalet algılarını maksimum seviyede olumlu düzeyde tutabilmektir çünkü kişi ancak örgüte karşı olumlu duygular beslerse olumlu katkılarda bulunmak isteyecektir. Aslına bakılırsa genel anlamda çalışanlar kendilerini diğerleriyle kıyaslayarak bu algıyı oluştururlar. Yöneticiler herkese eşit davransa da bazı durumlarda eşit davranmak yerine adaletli davranmak daha doğru bir karar olabilir ve bu durumun çıtıları daha olumlu davranışların ortaya çıkmasını doğurabilir. Yöneticilerin çalışanlar arasında adaletsizlik yapması, örgütsel sessizlik gibi olumsuz davranışların sergilenmesine yol açabilir. Aynı zamanda yöneticilerin adaletli veya adaletsiz davranışı sonrası çalışanlar, yöneticilerin etik ve ahlaki davranışları 
hakkında fikir edineceklerdir. Adaletli uygulamaların olmadığı bir örgütte çalışanların işlerine ve örgütlerine odaklanması ve yöneticisine güvenemeden örgütüne güvenmesi beklenemez. Birbirlerine güvenmeyen çalışan-yönetici ilişkisinden oluşan bir örgütün de bütünlük içerisinde olması beklenemez.

Sonuçlara ve analizlere dayanarak; sürekli değişen ve gelişen dünya karşısında kendini de sürekli yenilemek durumunda kalan üniversite yönetimlerinin başarılı olabilmesinde etken gruplardan birisi olan akademisyenler üzerindeki araştırmalara ve yorumlamalara daha çok yer ayrılması gerekmektedir. Akademisyenlerin süreçlere aktif katılımının sağlanması yönünde desteklenmeleri, fikir ve görüşlerini açıklıkla dile getirmeleri için gerekli örgüt iklimi oluşturulmalı, gerekirse iletişim kanalları yeniden düzenlenmelidir. Böylelikle, akademisyenlerin mesleki doyum düzeyleri artarak üniversite çıktılarına daha olumlu katkıda bulunabileceği değerlendirilmektedir. Ayrıca, makro düzeyde de yöneticilere, örgütsel adalet algısının yöneticiye güven duyulduğu bir ortamda artmasının örgütsel sessizliği azaltması yönünde şu öneriler verilebilir; çalışanları yaratıcı fikirler sunmaya teşvik etmek, çalışanlara performanslarına, göre yaratıcı inanç ve fikirlere uygun bir ödüllendirme sistemi oluşturmak, çalışanlarının yeni ve uygulamalı fikirlerini hayata geçirmek için örgütlerde çalışma grupları ve komitelere önem vermek, yöneticilere ve çalışanlara iletişim ve yönetim becerileri eğitimi konulu eğitim kursları düzenlemek ve yöneticiler ve çalışanlar için yeni yönetim teknikleri yetiştirmek gibi.

Çalışmanın bazı sınırlılıkları mevcuttur. Birincisi, kesitsel bir çalışmadır. Boylamsal bir çalışma ile örgütsel sessizliğin incelenmesi ve örgütsel adalet ile etkileşimi ve yöneticiye duyulan güvenin düzenleyici rolü, daha güvenilir bulgular ortaya çıaracaktır. Gelecekte, katılımcı özelliklerine ve kişi algılarını etkileyebilecek birçok değişkene odaklanarak farklı çalışmalar yapılabilir. Ayrıca verilerin toplandığı kurum kültürlerine göre de sonuçlar değişebilecektir. Bu nedenle bazı kültürel konular da dikkate alınarak çalışmanın evren ve örneklemi değiştirilerek tekrarlanabilir. Bu çalışmada örgütsel adalet algısı üç boyutlu olarak ele alınırken örgütsel sessizlik ve yöneticiye duyulan güven tek boyutlu olarak kullanılmıştır. Derinlemesine araştırma yapmak için bu değişkenlerin çeşitli boyutları ele alınarak farklı modeller kurularak çalışmalar yapılabilir. Ortak yöntem sapması, bu çalışmanın bir başka kısıtlamasıdır. Gelecekte, yöneticiye duyulan güvenin aracılık rolü, örgütsel kültür, iletişim iklimi ve örgütsel bağlllığın da sessizlikle ilişkisi incelenebilir.

\section{Hakem Değerlendirmesi / Peer-review:}

Dış bağımsız

Externally peer-reviewed

\section{Çıkar Çatışması / Conflict of interests:}

Yazar(lar) çıkar çatışması bildirmemiştir.

The author(s) has (have) no conflict of interest to declare.

\section{Finansal Destek / Grant Support:}

Yazar(lar) bu çalışma için finansal destek almadığını beyan etmiştir.

The author(s) declared that this study has received no financial support.

\section{Etik Kurul Onayı / Ethics Committee Approval:}

Bu çalışma için etik kurul onayı, Milli Savunma Üniversitesi, Sosyal ve Beşerî Bilimler Etik Kurulu/Komitesinden 18/05/2021 tarihli karar ile alınmıştır.

Ethics committee approval was received for this study from National Defense University, Social and Humanities Ethics Committee on 18/05/2021 document number.

\section{Yazar Katkıları / Author Contributions:}

Fikir/Kavram/Tasarım - Idea/Concept/ Design: A.U.K., M.B. Veri Toplama ve/veya İşleme - Data Collection and/or Processing: A.U.K., M.B. Analiz ve/veya Yorum - Analysis and/or Interpretation: A.U.K., M.B. Kaynak Taramas1 - Literature Review: A.U.K., M.B. Makalenin Yazım1 - Writing the Article: A.U.K., M.B. D.G. Eleştirel İnceleme - Critical Review: A.U.K., M.B. Onay - Approval: A.U.K., M.B. 


\section{Kaynakça / References}

Adams, J. S. (1965). Inequity in Social Exchange. (Ed. Berkowitz, L.). In: Advances in Experimental Social Psychology. New York: Academic Press, 267-299.

Alkayış, L. (2015). Mobbing ve Örgütsel Sessizliğin Çalışanların Motivasyonu Üzerine Etkisi.Yayımlanmamış Yükseklisans Tezi, İstanbul Gelişim Üniversitesi Sosyal Bilimler Enstitüsü, İstanbul.

Alsalem, M., \& Alhaiani, A. (2007). Relationship between Organizational Justice and Employees Performance. Aledari, March, (108), 97-110.

Aryee, P. S., Budhwar, Z. \& Chen, X. (2002). Trust as a Mediator of the Relationship between Organizational Justice and Work Outcomes: Test of A Social Exchange Model. Journal of Organizational Behavior, 23 (3), 267-285.

Aylsworth, J. (2008). Change in the Workplace: Organizational Silence Can be Dangerous. Organizational Psychology Examiner. Erişim adresi: http://www.examiner.com.

Bagheri, G., Zarei, R., \& Aeen, M. N. (2012). Organizational Silence Basic Concepts and Its Development Factors. Ideal Type of Management, 1, 50.

Bakiev, E. (2013). The Influence of Interpersonal Trust and Organizational Commitment on Perceived Organizational Performance. Journal of Applied Economics and Business Research, 3(3), 166-180.

Baldwin, S. (2006). Organizational Justice. Institute for Employment Studies, 1-13.

Baron R. M., \& Kenny, D. A. (1986). The Moderator-Mediator Variable Distinction in Social Psychological Research: Conceptual, Strategic, and Statistical Considerations. J Pers Soc Psychol 51:1173-82.

Beugre, C. D. (1998). Implementing Business Process Reengineering: The Role of Organizational Justice. The Journal of Applied Behavioral Science, 34(3), 347-360.

Blader, S. L., \& Tyler, T. R. (2003). A Four-Component Model of Procedural Justice: Defining the Meaning of a "Fair" Process. Personality and Social Psychology Bulletin, 29 (6), 747-758.

Blau, P. (1964). Power and Exchange in Social Life. New York, NY: John Wiley \& Sons

Bies, R. J., \& Moag, J. S. (1986). Interactional Justice: Communication Criteria of Fairness. Research on Negotiation in Organizations, 1, 43-55.

Binikos, E. (2010). Sounds of Silence: Organizational Trust and Decisions to Blow The Whistle. SA Journal of Industrial Psychology, 34(3), 48-59.

Brinsfield, C. (2009) Employee Silence: Investigation of Dimensionality, Development of Measures, And Examinatıon of Related Factors Dissertation, Yayımlanmamış Doktora Tezi, Ohio State University.

Brinsfield, C. T., Edwards, M. S., \& Greenberg, J. (2009). Voice and Silence in Organizations: Historical Review and Current Conceptualizations. Emerald Group Publishing Limited, 1st Edition, UK

Brockner, J., Siegel, P.A., Daly, J.P., Tyler, T., \& Martin, C.; (1997). When Trust Matters: The Moderating Effect Of Outcome Favorability. Administrative Science Quarterly, 42, 558-583.

Büyüköztürk, Ş., Çakmak, E., Akgün, Ö. Karadeniz, Ş., \& Demirel, F. (2008). Bilimsel Araştırma Yöntemleri. Ankara: Pegem Akademi.

Charash, Y. C.., \& Spector, P. E. (2001). The Role of Justice in Organizations: A Meta-Analysis. Organizational Behavior and Human Decision Processes, 86 (2), 278-321.

Colquitt, J. A. (2001). On The Dimensionality of Organizational Justice: A Construct Validation of a Measure. Journal of Applied Psychology, 86(3), 386-400.

Colquitt, J., \& Greenberg, J. (2003). Organizational Justice: A Fair Assessment of the State of the Literature. In J. Greenberg (Ed.), Organizational Behavior: The State of the Science. 2nd ed: 165-210. Mahwah, NJ: Lawrence Erlbaum

Cropanzona, R., \& Folger, R. (1998). Organizational Justice and Human Resource Management. London: Sage Publications, 1-304.

Cropanzano, R., \& Wright, T. A. (2003). Procedural Justice and Organizational Staffing: A Tale of Two Paradigms. Human Resource Management Review, 13, 7-39. 
Cropanzano, R., Bowen, D.E., \& Gilliland. S.W. (2007). The Management of Organizational Justice. Academy of Management Perspectives. November, 34-48

Çakıcı, A. (2010). Örgütlerde İşgören Sessizliği: Neden Sessiz Kalmayı Tercih Ediyoruz?, Detay Yayıncılık, Birinci Baskı, Ankara.

Çınar, O., Karcıoğlu, F., \& Alioğulları, Z. D. (2013). The Relationship Between Organizational Silence and Organizational Citizenship Behavior: A Survey Study in The Province of Erzurum, Turkey. Procedia-Social and Behavioral Sciences, 99, 314-321.

Dabbagh, P., Esfahani, A. N., \& Shahin, A. (2012). Studying Relationship Between Perceived Organizational Justice and Organizational Silence (Case study: Khorshid hospital's personals). Institute of Interdisciplinary Bus, Res. 3(10):468-478.

Demir, N. (2008). Liderlik Tarzının Örgütsel Adalet ile İlişkisi ve Lidere Olan Güvenin Bu İlişkideki Rolü. Öneri, 8(30), 195-205.

Demircan, N. (2003). Örgütsel Güvenin Bir Ara Değişken Olarak Örgütsel Bağlllık Üzerindeki Etkisi: Eğitim Sektöründe Bir Uygulama. (Doktora Tezi). Gebze Yüksek Teknoloji Sosyal Bilimler Enstitüsü, Gebze.

Demirel, Y. (2009). Örgütsel Bağlılık ve Üretkenlik Karşıtı Davranışlar Arasındaki İlişkiye Kavramsal Yaklaşım. İstanbul Ticaret Üniversitesi Sosyal Bilimler Dergisi, 8 (15), 115-132.

Demırkaya, A, H., \& Şimşek Kandemir, A. (2014). Örgütsel Adaletin Boyutları ile Örgütsel Güven Arasındaki İlişkinin Analizine Yönelik Bir İşletme İncelemesi. Atatürk Üniversitesi Sosyal Bilimler Enstitüsü Dergisi, 18 (2): 263-279

Dirks, K. T., \& Ferrin, D. L. (2002). Trust in Leadership: Meta-Analytic Findings and Implications for Research and Practice. Journal of Applied Psychology, 87.4, 611-628.

Durak, İ. (2014). Örgütsel Sessizliğin Demografik ve Kurumsal Faktörlerle İlişkisi: Öğretim Elemanları Üzerine Bir Araştırma. Atatürk Üniversitesi İktisadi ve İdari Bilimler Dergisi, 28(2), 89-108

Ellonen, R., Blomqvist, K., \& Puumalainen, K. (2008). The Role of Trust in Organization Innovativeness. European Journal of Innovation Management, 11(2), 160-181. Erişim adresi: http://dx.doi.org/10.1108/14601060810869848.

Fard, P., \& Karimi, P. (2015). The Relationship between Organizational Trust and Organizational Silence with Job Satisfaction and Organizational Commitment of the Employees of University. International Education Studies, 8 (11).

Fitzroy, T. (2007). The Importance of Organizational Trust. Best Advice Forum. Erişim adresi: http://www.articlesbase.com.

Folger, R., \& Konovsky, M. A. (1989). Effects of Procedural and Distributive Justice on Reactions to Pay Raise Decisions. Academy of Management Journal, 32,115-130.

Fortin, M. (2010). Perspectives on Organisational Justice: Concept Clarification, Social Context İntegration, Time and Links With Morality. International Journal of Management Reviews, 2 (10), 93-126.

Gao, L., Janssen, O., \& Shi, K. (2011). Leader Trust and Employee Voice: The Moderating Role of Empowering Leader Behaviors. The Leadership Quarterly, 22, 787-798

Greenberg, J. (1987). A Taxonomy of Organizational Justice Theories. The Academy of Management Review, 12(1), 9-22

Günce, S. (2013). İlköğretim Okullarında Örgütsel Adalet ile Örgütsel Bağlllık İlişkisi (Yayımlanmamış Yükseklisans Tezi). Harran Üniversitesi Sosyal Bilimler Enstitüsü.

Güngör, S. K., \& Potuk, A. (2018). Öğretmenlerin Mobbing, Örgütsel Adalet ve Örgütsel Sessizlik Algıları ve Aralarındaki İlişki. Hacettepe Üniversitesi Eğitim Fakültesi Dergisi, (1), 1-20.

Güvenli, D. (2014). Örgütsel Adalet Algısı ve Tükenmişlik Sendromunun Örgütsel Sessizlik Üzerindeki Etkisi Emniyet Mensupları Üzerinde Bir Araştırma. Yüksek Lisans Tezi. Haliç Üniversitesi Sosyal Bilimler Enstitüsü.

Hayes, A. F. (2018). Introduction to Mediation, Moderation, and Conditional Process Analysis: A Regression-Based Approach. New York: The Guilford Press. 
Jawahar, I. M. (2002). A Model of Organizational Justice and Workplace Aggression. Journal of Management, 28(6) 811-834.

Jones, G., \& George, J. (1998). The Experience and Evolution of Trust: İmplications for Cooperation and Teamwork. The Academy of Management Review, 23(3), 531-546.

Johnson, J. P., Korsgaard, M. A. \& Sapienza, H. J. (2002). Perceived Fairness, Decision Control, and Commitment in International Joint Venture Management Teams. Strategic Management Journal, 23 (12), 1141-1160.

Jung, D. I., \& Avolio, B. J. (2000). Opening the Black Box: An Experimental Investigation of The Mediating Effects of Trust and Value Congruence on Transformational and Transactional Leadership. Journal of Organizational Behavior, 21(8), 949-964.

Horn Nord, J., Paliszkiewicz, J., Koohang, A., \& Gołuchowski, J. (2014). Management Trust, Organizational Trust, and Organizational Performance Advancing and Measuring A Theoretical Model. Management and Production Engineering, 5(1), 32-41.

İşcan, Ö. F., \& Sayın, U. (2010). Örgütsel Adalet, İş Tatmini ve Örgütsel Güven Arasındaki İlişki. Atatürk Üniversitesi İ̈BF Dergisi, 24(4), 195-216.

Karacaoğlu, K., \& Cingöz, A. (2009). İş Gören Sessizliğinin Kaynağı Olarak Liderlik Davranışı ve Örgütsel Adalet Algısı. 17. Ulusal Yönetim ve Organizasyon Kongresi Bildiri Kitabı, 700-707.

Khanifar, H., Moghimi, M., Jandaghi, Gh., \& Zarvandy, N. (2009). Analysis of Relation between Elements of Trust and Organizational Commitment of Personnel (social welfare organization of Qom state and education organization of Qom state). Journal of Public Administration, 1(2), 3-18.

Kılıçlar, A. (2011). Yöneticiye Duyulan Güven ile Örgütsel Adalet ilişkisinin Öğretmenler Açısından İncelenmesi. İşletme Araştırmaları Dergisi, 3(3), 23-36.

Kim, W. C., \& Mauborgne, R. A. (1991). Implementing Global Strategies: The Role of Procedural Justice. Strategic Management Journal, 12, 125-143.

Kim, W. C., \& Mauborgne, R. A. (1993). Procedural Justice, Attitudes, and Subsidiary Top Management Compliance With Multinationals' Corporate Strategic Decisions. Academy of Management Journal, $36(3), 502-526$.

Konovsky, M. A., \& Pugh, S.D. (1994). Citizenship Behavior and Social Exchange. Academy of Management Journal, 37, 656-669.

Koçel T. (2014). İşletme Yöneticiliği, Yönetim ve Organizasyon, Organizasyonlarda Davranış KlasikModern-Çağdaş ve Güncel Yaklaşımlar. (15. Baskı). İstanbul: Beta Yayınları, 1- 855.

Korsgaard, M. A., Schweiger, D. M., \& Sapienza, H. J. (1995). Building Commitment, Attachment, and Trust in Strategic Decision-Making Teams: The Role of Procedural Justice. Academy of Management Journal, 38 (1), 60-84.

Lavelle, J. Brockner, M. A., Konovsky, K. H., Price, A. B., Henley, A. T., \& Vinekar, V. (2009). Commitment, Procedural Fairness, and Organizational Citizenship Behavior: A Multifoci Analysis. Journal of Organizational Behavior, 30 (3), 337-357.

Leventhal, G. S. (1980). What Should be done With Equity Theory? New Approaches to the Study of Fairness in Social Relationships. In K. Gergen, M. Greenberg \& R. Willis (Eds.), Social exchange: Advances in theory and research: 27-55. New York: Plenum.

Liao, W. C., \& Tai, W. T. (2006). Organizational Justice, Motivation to Learn, and Training Outcomes, Social Behavior and Personality, 34(5), 545-556.

Mayer, R. C., Davis, J. H., \& Schoorman, D. E. (1995). An Integrative Model of Organizational Trust. Academy of Management, 20(3), 709-734

McAllister, D. J. (1995). Affect-And Cognition-Based Trust as Foundations for Interpersonal Cooperation in Organizations. Academy of Management Journal, 38(1), 24-59.

McCain, S. C., Tsai, H., \& Bellino, N. (2010). Organizational Justice, Employees "ethical Behavior, and Job Satisfaction in The Casino Industry. International Journal of Contemporary Hospitality Management, 22(7), 992-1009.

Meydan, C. H., Köksal, K., \& Uğurlu Kara, A. (2016). Örgüt İçinde Sessizlik: Örgütsel Etik Değerlerin Etkisi ve Adalet Algısının Aracılık Rolü. İktisadi ve İdari Bilimler Fakültesi Dergisi, 17 (3), 142-159. 
Milliken, F.J., \& Morrison, E.W. (2003a). Shades of Silence: Emerging Themes and Future Directions for Research on Silence in Organizations. Journal of Management Studies, 40 (6), 1564-1568.

Milliken, F. J., Morrison, E. W., \& Hewlin, P. E. (2003b). An Exploratory Study of Employee Silence: Issues that Employees Don't Communicate Upward and Why. Journal of Management Studies, 6 (40), 1453-1476.

Mirmohammadi, S. M., \& Marefat, A. (2014). The Effect of Perceived Justice and Organizational Silence on Organizational Commitment, International Review of Management and Business Research, 3(3), 1773-1789.

Moorman, R. H. (1991). Relationship Between Organizational Justice and Organizational Citizenship Behaviors: do Fairness Perception Influence Employee Citizenship?. Journal of Applied Psychology, 76(6), 845-855.

Morrison, E. W., \& Milliken, F. J. (2000). Organizational Silence: A Barrier to Change and Development in A Pluralistic World. Academy of Management Review, 25, 706-731.

Nabatchi, T., Bingham, L.B., \& Good, D. H. (2007). Organizational Justice and Workplace Mediation: A Six Factor Model, International Journal of Conflict Management, 18 (2), 148-176.

Nielsen, R. P. (2003). Why do We Remain Silent in The Face of Unethical Behavior?. Occasional Paper, 6.

Nyhan, R. C., \& Marlowe, H. A. (1997). Development and Psychometric Properties of the Organizational Trust Inventory. Evaluation Review, 21(5), 614-635.

Organ, D. W. (1990). The Motivational Basis of Organizational Citizenship Behavior. In B. M. Staw \& L. L. Cummings (Eds.), Research in organizational behavior, Greenwich, CT: JAI Press. 12, 43-72

Önder, E. (2017). Ortaöğretim Okullarında Örgütsel Sessizliğin Yordayıcısı Olarak Örgütsel Adalet ve Örgütsel Bağllık, Ahi Evran Üniversitesi Kırşehir Eğitim Fakültesi Dergisi (KEFAD) 18 (2).

Özçınar, M. F., Demirel, Y., \& Özbezek, B. D. (2015). Çalışanların Örgütsel Adalet Algıları ve Örgütsel Sessizlik Arasındaki İlişkinin İncelenmesi. Mehmet Akif Ersoy Üniversitesi Sosyal Bilimler Enstitüsü Dergisi, 7 (13), 150-171.

Özmen, Ö., Arbak, Y., \& Özer P. (2007). Adalete Verilen Değerlerin Adalet Algıları Üzerindeki Etkisinin Sorgulanmasına İlişkin Bir Araştırma. Ege Akademik Bakış, 7 (1), 17-33.

Park, W., \& Keil, M. (2009). Organizational Silence and Whistle. Blowing on IT Projects: An Integrated Model. Decision Sciences, 40(4), 901-918.

Pillai, R., Schriesheim, C. A., \& Williams, E. S. (1999). Fairness Perceptions and Trust as Mediators for Transformational and Transactional Leadership: A Two-Sample Study. Journal of Management, 25(6), 897-933.

Pinder, C. C. \& Harlos, K. P. (2001). Employee Silence: Quiescence and Acquiescence as Responses to Perceived İnjustice. Research in Personnel and Human Resources Management, K. M. Rowland and G. R. Ferris eds., New York: JAI Press, 20, 331-369.

Podsakoff, P. M., MacKenzie, S. B., Moorman, R. H., \& Fetter, R. (1990). Transformational Leader Behaviors and Their Effects on Followers' Trust in Leader, Satisfaction, and Organizational Citizenship Behaviors. The Leadership Quarterly, 1(2), 107- 142.

Radmard, S. G., \& Afkhami A. M. (2014). Effect of Organizational Culture on Organizational Silence: The Mediating Role of Organizational Commitment, International Journal of Management and Humanity Sciences, 3 (10), 3306-3313.

Sheik-Mohamed, L., Mohiadeen, A. K. M., \& Anisa, H. (2012). Relationship among Organizational Commitment, Trust and Job Satisfaction: An Empirical Study in Banking Industry. Research Journal of Management Sciences, 1(2), 1-7.

Sözen, C., Yeloğlu, H. O. ve Ateş, F. (2009). Eşitsizliğe Karşı Sessiz Kalma: Mavi Yakalı Çalışanların Motivasyon Üzerine Görgül Bir Çalışma. Selçuk Üniversitesi Sosyal Bilimler Enstitüsü Dergisi, (22), 395-408.

Steiner, D., D., \& Bertolino, M. (2006). The Contributions of Organizational Justice Theory to Combating Discrimination. Cahiers de l'Urmis, Discrimination: Perspectives de la Psychologie Sociale et de la sociologie, (1-9). 
Tan, Ç. (2014). Organizational Justice as a Predictor of Organizational Justice, Educational Research and Reviews, 9, 1190-1202.

Taşçıŏlu, H. (2010). Örgüt Kültürünün Örgütsel Adalete Etkisi: Bir Örnek Olay. Doktora Tezi, Sakarya Üniversitesi Sosyal Bilimler Enstitüsü, Sakarya.

Thibaut, J., \& Walker, L. (1975). Procedural Justice: A Psychological Analysis. Hillsdale, N.J.: Lawrence Erlbaum Associates, Publishers.

Tulubas, T., \& Celep, C. (2012). Effect Of Perceived Procedural Justice on Faculty Members' Silence: The Mediating Role of Trust in Supervisor, Procedia - Social and Behavioral Sciences, 47, 1221 - 1231

Usmani, S., \& Jamal, S. (2013). Impact of Distributive Justice, Procedural Justice, Interactional Justice, Temporal Justice, Spatial Justice on Job Satisfaction of Banking Employees, Review of Integrative Business \& Economics Research, 2(1), 351-383.

Ülker, G. (2008). Çalışanların Örgütsel Adalet Algılamalarının Yönetici ve Örgüte Duyulan Güven Üzerindeki Etkisi. Sosyal Bilimler Enstitüsü Dergisi, 9 (16), 188-208.

Ünler, E. (2015). Ses; Kapı Çalınıyor, Duyan Var mı?. İ. Tamer (Ed). Örgüt Yönetimi: Bir Derleme içinde. İstanbul: Nobel Yayın, 2015, 1-16

Van Dyne, L., Ang, S., \& Botero, I. C. (2003). Conceptualizing employee silence as multidimensional constructs. Journal of Management Studies, 40, 1359-1392.

Vakola, M. and Bouradas, D. (2005). Antecedents and Consequences of Organizational Silence: An Empirical Investigation. Employee Relations, 27 (5), 441-458.

Wang, S., Tomlinson, E. C., \& Noe, R. A. (2010). The Role of Mentor Trust and Protégé Internal Locus of Control in Formal Mentoring Relationships. Journal of Applied Psychology, 95(2), 358

Yang, J., Mossholder, K. W., \& Peng, T. K. (2009). Supervisory Procedural Justice Effects: The Mediating Roles of Cognitive and Affective Trust. The Leadership Quarterly, 20(2), 143-154

Yang, J., \& Mossholder, K. W. (2010). Examining The Effects of Trust in Leaders: A Bases-And-Foci Approach. The Leadership Quarterly, 21(1), 50-63.

Yeşil, Salih, Yüksel, M., \& Hatunoğlu, M. (2020). Örgütsel Adaletin Örgütsel Bağlllığa Etkisi: Bir Alan Araştırması. Çukurova Üniversitesi Sosyal Bilimler Enstitüsü Dergisi, 29(3), 568-598

Zoghbi-Manrique-de-Lara, P. (2010). Do Unfair Procedures Predict Employees' Ethical Behavior by Deactivating Formal Regulations? Journal of Business Ethics, 94, 411-425. 